\title{
When does higher spatial resolution rainfall information improve streamflow simulation? An evaluation using 3620 flood events
}

\author{
F. Lobligeois ${ }^{1}$, V. Andréassian ${ }^{1}$, C. Perrin ${ }^{1}$, P. Tabary ${ }^{2}$, and C. Loumagne ${ }^{1}$ \\ ${ }^{1}$ Irstea, Hydrosystems and Bioprocesses Research Unit, Antony, France \\ ${ }^{2}$ Direction des Systèmes d'Observation - Météo France, Toulouse, France \\ Correspondence to: F. Lobligeois (florent.lobligeois@irstea.com) \\ Received: 9 September 2013 - Published in Hydrol. Earth Syst. Sci. Discuss.: 16 October 2013 \\ Revised: 28 December 2013 - Accepted: 14 January 2014 - Published: 17 February 2014
}

\begin{abstract}
Precipitation is the key factor controlling the highfrequency hydrological response in catchments, and streamflow simulation is thus dependent on the way rainfall is represented in a hydrological model. A characteristic that distinguishes distributed from lumped models is the ability to explicitly represent the spatial variability of precipitation. Although the literature on this topic is abundant, the results are contrasting and sometimes contradictory. This paper investigates the impact of spatial rainfall on runoff generation to better understand the conditions where higher-resolution rainfall information improves streamflow simulations. In this study, we used the rainfall reanalysis developed by MétéoFrance over the whole country of France at $1 \mathrm{~km}$ and $1 \mathrm{~h}$ resolution over a $10 \mathrm{yr}$ period. A hydrological model was applied in the lumped mode (a single spatial unit) and in the semidistributed mode using three unit sizes of subcatchments. The model was evaluated against observed streamflow data using split-sample tests on a large set of French catchments (181) representing a variety of sizes and climate conditions. The results were analyzed by catchment classes and types of rainfall events based on the spatial variability of precipitation. The evaluation clearly showed different behaviors. The lumped model performed as well as the semidistributed model in western France, where catchments are under oceanic climate conditions with quite spatially uniform precipitation fields. By contrast, higher resolution in precipitation inputs significantly improved the simulated streamflow dynamics and accuracy in southern France (Cévennes and Mediterranean regions) for catchments in which precipitation fields were identified to be highly variable in space. In all regions, natural variability allows for contradictory examples to be found, showing that analyzing a large number of events over varied catchments is warranted.
\end{abstract}

\section{Introduction}

A review of the hydrologic literature shows that there is no consensus on the impact of spatial resolution on the performance of hydrological models (e.g., Reed et al., 2004; Smith et al., 2012). There are several reasons for this. First, most previous studies have been limited to a single catchment or only a few catchments (Ajami et al., 2004; Bell and Moore, 2000; Das et al., 2008; Finnerty et al., 1997; Lindström et al., 1997; Reed et al., 2004; Smith et al., 2004, 2012; Winchell et al., 1998; Zhang et al., 2004), which makes conclusions highly dependent on the characteristics of the catchments studied. Interestingly, their contradictory conclusions show that the impact of the rainfall spatial distribution on runoff depends on catchment and event characteristics (Segond et al., 2007; Singh, 1997; Tetzlaff and Uhlenbrook, 2005; Viglione et al., 2010; Woods and Sivapalan, 1999; Zoccatelli et al., 2011). Second, many studies are virtual experiments based on synthetic flows, in which model simulations are compared to other simulations chosen as references. This makes it difficult to reach conclusions transposable to actual case studies (Andréassian et al., 2004; Das et al., 2008). Lastly, the parameterization strategies used may introduce a bias in the evaluation of modeling approaches with different resolutions if parameters are not recalibrated or rescaled at each spatial resolution investigated (Kampf and Burges, 2007; Koren et al., 1999; Kumar et al., 2013; Morin et al., 2001; Samaniego et al., 2010).

That being said, the sensitivity of hydrological simulations to the spatial variability of precipitation inputs has been an active research area over the last three decades. There are at least two origins for this sensitivity: (1) the density of the precipitation measurement network, which more or less 
finely samples the actual precipitation field, and (2) the inadequacy of the rainfall-runoff models' structure and spatial discretization. This review will not examine the first point, which has already been widely studied. All authors who have written on this subject agree that spatial rainfall measurement is important on all scales, and that its importance increases as catchment size decreases (Beven and Hornberger, 1982; Ogden and Julien, 1993; Michaud and Sorooshian, 1994; Obled et al., 1994; Faures et al., 1995; Shah et al., 1996; Winchell et al., 1998; Sun et al., 2000; Carpenter et al., 2001; Andréassian et al., 2001; Berne et al., 2004; Arnaud et al., 2011; Vaze et al., 2011; Emmanuel et al., 2012).

Let us here focus on the relationship between spatial rainfall representation and runoff response. Results presented in the literature are contrasting and sometimes contradictory. Several studies concluded that including more detailed information on rainfall spatial distribution improves discharge simulation, whereas other studies, surprisingly, have shown a lack of significant improvement in simulations. A variety of studies have shown little (or no) impact of explicitly accounting for rainfall variability, and several authors have suggested that a correct assessment of the rainfall input volume is more important than the rainfall spatial pattern itself (even in a highly spatially variable pattern) for simulating streamflow hydrographs (Andréassian et al., 2001; Beven and Hornberger, 1982; Naden, 1992; Obled et al., 1994; Woods and Sivapalan, 1999). Other studies have tested different modeling configurations, from lumped to (semi-) distributed, in order to investigate the impact of spatial precipitation inputs on streamflow simulations. Many of them reported that increased resolution in space had little effect on the model's performance and that distributed modeling approaches may not always provide improved outlet simulations compared to lumped approaches (Ajami et al., 2004; Apip et al., 2012; Bell and Moore, 2000; Das et al., 2008; Lindström et al., 1997; Liu et al., 2012; Naden, 1992; Nicòtina et al., 2008; Obled et al., 1994; Reed et al., 2004; Refsgaard and Knudsen, 1996; Smith et al., 2004; Zhang et al., 2004).

However, other studies have found that runoff prediction errors were considerably higher when spatially averaged rainfall was used, and that including explicit information on rainfall spatial distribution improved the quality of predicted streamflow (Bonnifait et al., 2009; Carpenter and Georgakakos, 2006; Cole and Moore, 2008; Dodov and Foufoula-Georgiou, 2005; Krajewski et al., 1991; Ogden and Julien, 1994; Saulnier and Le Lay, 2009; Singh, 1997; Tramblay et al., 2011; Winchell et al., 1998; Yu et al., 2012). Of these studies, some have underlined that the improvements in streamflow modeling were not systematic (Arnaud et al., 2011; Koren et al., 2004; Nicòtina et al., 2008; Segond et al., 2007; Tetzlaff and Uhlenbrook, 2005; Viglione et al., 2010; Winchell et al., 1998). They argued that improvements were only significant in catchments with significant spatial rainfall variability (Arnaud et al., 2002, 2011; Koren et al., 2004) and for large catchments, due to the greater need for considering the distribution of spatial rainfall gradients (Nicòtina et al., 2008; Vaze et al., 2011). Others have attempted to explain the differences by different runoffgenerating processes, strongly dependent on soil characteristics and soil moisture, which interact with rainfall characteristics (Merz and Blöschl, 2009; Merz et al., 2006; Nicòtina et al., 2008; Norbiato et al., 2009; Penna et al., 2011; Viglione et al., 2010). These points of view suggest that rainfall-runoff processes are strongly variable between catchments and rainfall events.

It is our opinion that the previous studies have investigated too few catchments and too few flood events to draw any definitive conclusions. To reach general conclusions on the link between rainfall spatial variability and hydrological model performance, this paper presents tests made on a large set of events showing various spatial patterns of precipitation fields in different types of hydroclimatic conditions: this study uses a large set of flood events (3620) observed in 181 catchments in France that represent a variety of conditions. A common model setup, calibration and testing framework was applied for the various modeling options tested.

The catchment set and hydrological model are presented in Sect. 2. Section 3 details model implementation and the methods used to evaluate the streamflow simulations. Then the results are discussed in Sect. 4, starting with the analysis of the entire data set and then distinguishing different behaviors. The conclusions are summarized in Sect. 6 .

\section{Data and study area}

\subsection{A high-resolution precipitation data set}

Weather radar provides rainfall estimates with high temporal and spatial resolution, but unfortunately, despite the major progress that has been made over the past decades on understanding and correcting radar errors, radar quantitative precipitation estimation products may still occasionally suffer from biases that may significantly affect rainfallrunoff simulations. Consequently, the benefit that could be gained from the improved spatial resolution of rainfall estimates has often been limited in hydrological applications (Biggs and Atkinson, 2011; Borga, 2002; Delrieu et al., 2009; Emmanuel et al., 2011; Krajewski et al., 2010).

Météo-France, the French national weather service, has recently produced a $10 \mathrm{yr}$ (1997-2006) quantitative precipitation reanalysis at the hourly time step and $1 \mathrm{~km}^{2}$ spatial resolution (Tabary et al., 2012). This reference data set combines all the information available in the operational archives (manual and automatic rain gauges as well as weather radars) in order to obtain the best precipitation estimation over France $\left(550000 \mathrm{~km}^{2}\right)$. Figure 1 presents the location of available weather radar and rain gauge data in operation between 1997 and 2006. The French operational network was based 


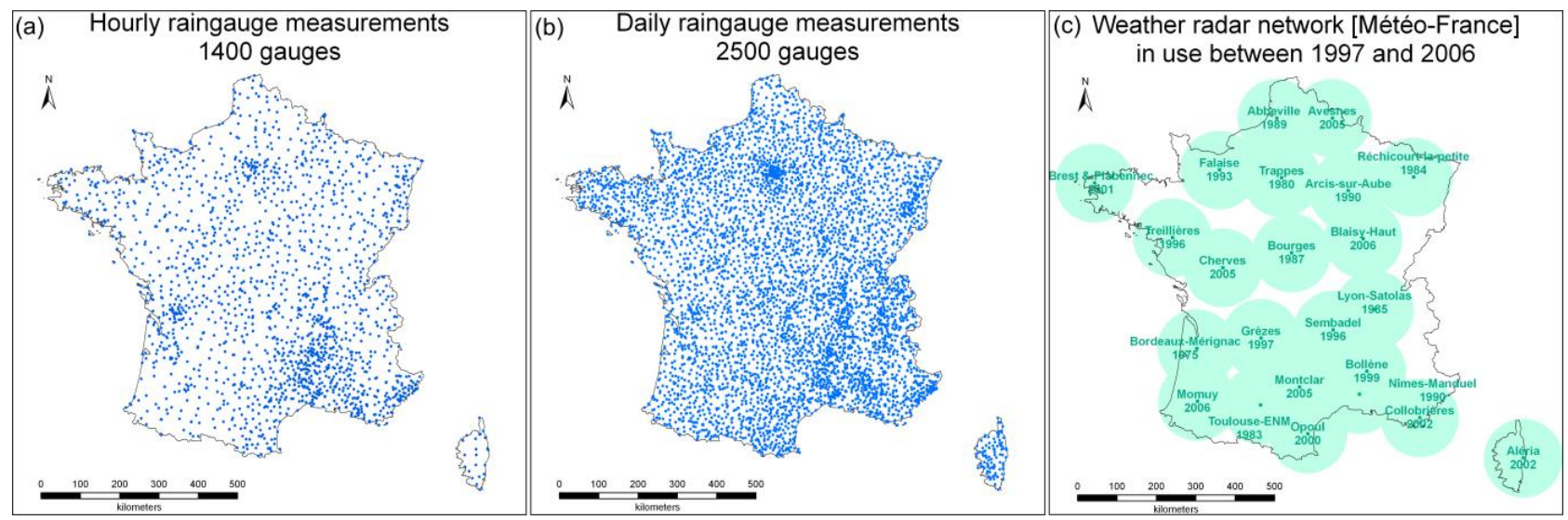

Fig. 1. Structures of the operational measurement network for precipitation estimates between 1997 and 2006. (a) Automatic hourly rain gauge network; (b) daily manual rain gauge network; (c) theoretical coverage of the weather radar (location name and year of installation are indicated).

on 13 radars in 1997, and 10 additional radars have been deployed over the 1997-2006 period, increasing the total number of operational radars to 23 in 2006 . The ground measurement network consists of 1400 automatic and 2500 manual rain gauges (from which hourly and daily time series, respectively, can be derived).

We give a short description of the procedure followed by Météo-France to establish the reanalysis, but further detail can be found in Tabary et al. (2012). These data treatments are based on the operational experience of radar data processing at Météo-France. The precipitation data from the rain gauge network are routinely checked and corrected by expert systems. The radar network provides reflectivity images every $5 \mathrm{~min}$, which are pre-processed before being merged with rain gauge data. The reflectivity images are corrected for residual ground-clutter, clear air echoes (affected by insects, dusts, etc.), partial beam blocking, and undersampling effects before being converted into rainfall rates using the Marshall Palmer $Z-R$ relationship. Daily calibration factors are computed for every $1 \mathrm{~km}^{2}$ pixel by comparing $24 \mathrm{~h}$ accumulated radar rainfall rates and daily rain gauge estimates computed from hourly and daily gauge measurements by kriging with external drift. Hourly radar rainfall accumulations are then corrected using the daily calibration factors. Finally, hourly precipitation accumulation fields are computed from the available hourly (calibrated) radar and rain gauge data using kriging with external drift. For the time steps when no radar data are available or in cases for which no calibration factor can be computed, the composite map is filled by ordinary kriging of hourly rain gauge data.

The final composite $1 \mathrm{~km}^{2}$ hourly rainfall estimates have been successfully validated against independent hourly rain gauge data (not used for the whole reanalysis process) over $1 \mathrm{yr}$ in southeastern France (Tabary et al., 2012). Hence, the reanalysis can be considered to provide reliable hourly precipitation estimations with high spatial resolution suitable for

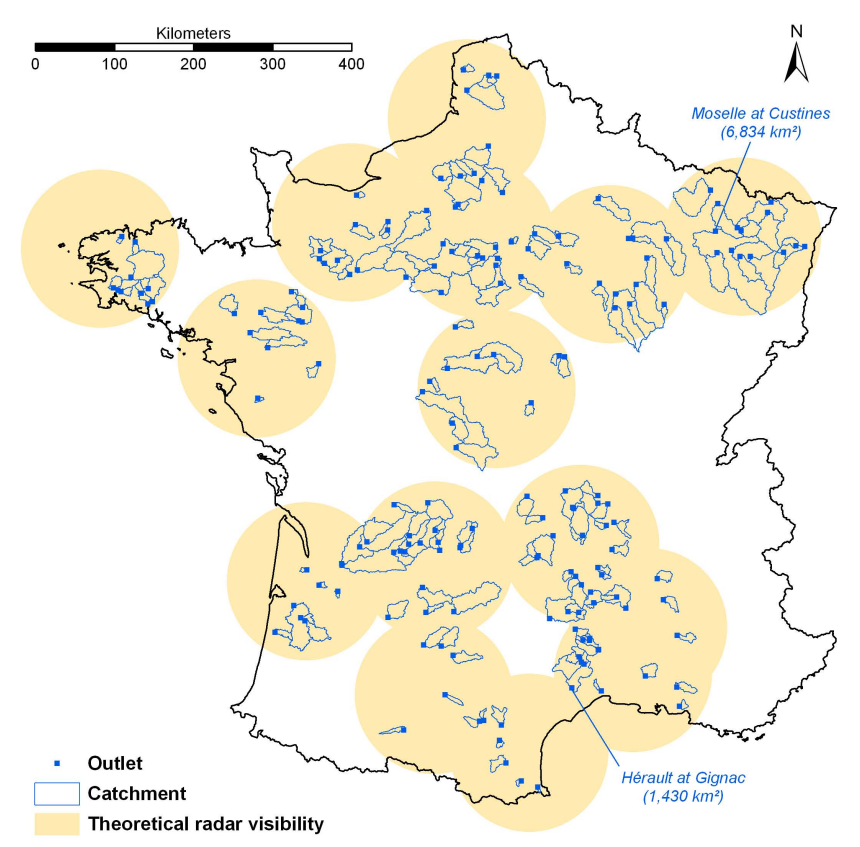

Fig. 2. Locations of the 181 French catchments used in this study.

the investigation of the impact of rainfall spatial variability on the catchment response.

\subsection{Catchment data set}

A large set (181) of French catchments (see Fig. 2) was selected to run semidistributed rainfall-runoff simulations. Hourly discharge data at the basin outlets were obtained from the HYDRO national archive (www.hydro.eaufrance.fr) for the $10 \mathrm{yr}$ period of the rainfall reanalysis (1997-2006). Since weather radar measurements are considered accurate within a $100 \mathrm{~km}$ radius, the catchments were selected within this distance. 
Table 1. Summary of physiographical and hydrometeorological characteristics of the catchment set. The rainfall intensity coefficient is the ratio between the 99 th percentile $P_{99}$ and the mean hourly precipitation $P_{\mathrm{m}}$.

\begin{tabular}{llll}
\hline Basin characteristics & Min & Median & Max \\
\hline Drainage area $\left(\mathrm{km}^{2}\right)$ & 16 & 264 & 6834 \\
Mean elevation $(\mathrm{m})$ & 41 & 250 & 1276 \\
Mean slope $(-)$ & 0.01 & 0.06 & 0.37 \\
Annual runoff, $Q(\mathrm{~mm})$ & 57 & 307 & 1228 \\
Annual precipitation, $P(\mathrm{~mm})$ & 489 & 913 & 1841 \\
Annual potential evapotranspiration, PE (mm) & 556 & 696 & 892 \\
Runoff coefficient, $Q / P(-)$ & 0.10 & 0.33 & 0.80 \\
Aridity index, $P / \mathrm{PE}(-)$ & 0.55 & 1.33 & 2.85 \\
Rainfall intensity coefficient, $P_{99} / P_{\mathrm{m}}(-)$ & 14 & 19 & 28 \\
Streamflow 6h autocorrelation $(-)$ & 0.52 & 0.97 & 1.00 \\
\hline
\end{tabular}

The catchment data set represents a wide variety of physiographical and hydroclimatic conditions (Fig. 2), ranging from oceanic to Mediterranean. This catchment set consists of small to medium-sized catchments, with 32 catchments smaller than $100 \mathrm{~km}^{2}$ and 27 catchments larger than $1000 \mathrm{~km}^{2}$. The largest catchment is the Moselle at Custines $\left(6834 \mathrm{~km}^{2}\right)$ in northeastern France. The characteristics of rainfall events on these catchments also vary, with both stratiform and convective events with a wide range of intensities. Higher values of the rainfall intensity coefficient (calculated as the ratio between the 99th percentile and the mean hourly precipitation) and lower values of the streamflow $6 \mathrm{~h}$ autocorrelation coefficient (Table 1) are found in basins located in southeastern France in the Cévennes region and Mediterranean area where strong convective storms and flash floods are frequent (Berne et al., 2009; Delrieu et al., 2005; Javelle et al., 2010; Saulnier and Le Lay, 2009). Note that mountainous catchments were intentionally not selected here due to large uncertainties in radar measurements. Hence, there is no significant snow influence in the catchments studied.

\section{Methodology}

\subsection{The semidistributed rainfall-runoff model}

We used a semidistributed model derived from the work of Lerat (2009). It is based on the GR5H hourly lumped rainfall-runoff model proposed by Le Moine (2008) (Fig. 3). The GR5H model only has five free parameters (see Fig. 3 and Table 2).

In the semidistributed model, the catchment is divided into hydrologic units (i.e., subcatchments) following the drainage network. A digital elevation model was used to build the subcatchments (O'Callaghan and Mark, 1984). We chose to use subcatchments of roughly the same size (Fig. 4). Mean rainfall is calculated for each subcatchment (Fig. 5) and used as input to the GR5H model applied in lumped mode to simulate the outflow of each hydrological unit. Then a channel-routing
Table 2. List of the parameters for the semidistributed version of the conceptual rainfall-runoff GR5H model.

\begin{tabular}{ll}
\hline $\begin{array}{l}\text { Model } \\
\text { parameter }\end{array}$ & Description \\
\hline$X_{1}$ & Production (soil moisture accounting) store capacity $(\mathrm{mm})$ \\
$X_{2}$ & Groundwater exchange coefficient $(-)$ \\
$X_{3}$ & Time base of the unit hydrograph $(h)$ \\
$X_{4}$ & Routing store capacity $(\mathrm{mm})$ \\
$X_{5}$ & Threshold for groundwater exchange $(-)$ \\
$C$ & Average celerity in the river network $\left(\mathrm{m} \mathrm{s}^{-1}\right)$ \\
\hline
\end{tabular}

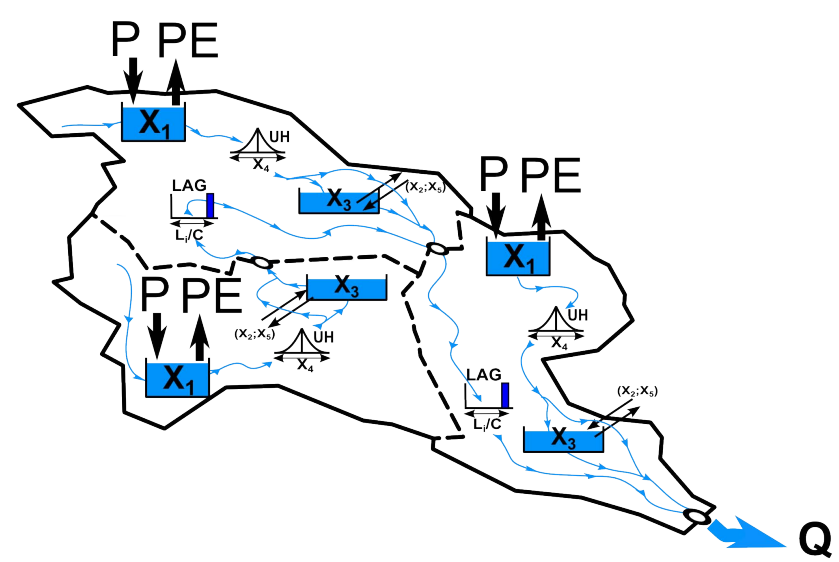

Fig. 3. Schematic representation of the semidistributed version of the GR5H rainfall-runoff model.

method is used to route the subcatchment flows to the downstream catchment outlet through the river network. Given the steep mean slope (greater than 0.01) for all the catchments (Table 1), the kinematic wave approximation can be considered valid to route natural flow in the river network (Henderson, 1966; Morris and Woolhiser, 1980). In this study, the linear lag propagation model (Bentura and Michel, 1997) was found to provide a satisfactory level of efficiency compared to more sophisticated channel routing methods. This is in agreement with the results of Lerat et al. (2012). This function has a single free parameter: average river flow celerity $C$ $\left(\mathrm{m} \mathrm{s}^{-1}\right)$.

The sensitivity of streamflow simulations to the spatial resolution of rainfall estimates was investigated by testing the semidistributed rainfall-runoff model for three sizes of subcatchments: $64 \mathrm{~km}^{2}$ (SD64), $16 \mathrm{~km}^{2}$ (SD16), and $4 \mathrm{~km}^{2}$ (SD04) (Fig. 4). The number of subcatchments per catchment ranges between 2 and 108 for SD64, 2 and 432 for SD16, and between 4 and 1733 for SD04. In each case, the subcatchment rainfall-runoff models were fed with rainfall inputs averaged over the subcatchment, as illustrated in Fig. 5. The lumped configuration was also tested so that it could serve as a reference, using precipitation averaged over the whole catchment as input. 


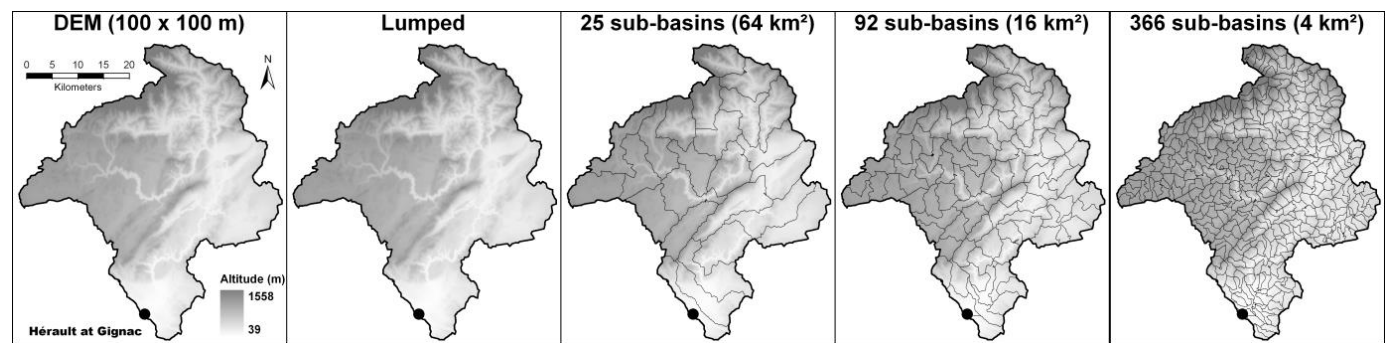

Fig. 4. Examples of lumped and semidistributed catchment discretizations (with unit sizes of 64,16 and $4 \mathrm{~km}^{2}$ ) for the Hérault catchment at Gignac $\left(1430 \mathrm{~km}^{2}\right)$.

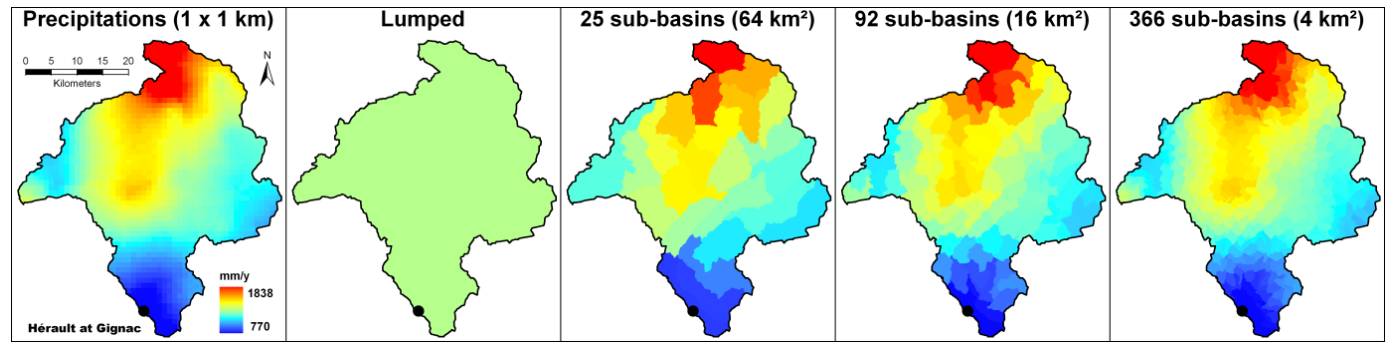

Fig. 5. Distributed precipitation forcing $\left(10 \mathrm{yr}\right.$ average) for the catchment discretizations of the Hérault catchment at Gignac $\left(1430 \mathrm{~km}^{2}\right)$ shown in Fig. 4.

\subsection{Model parameterization and calibration}

The calibration of a distributed or semidistributed model is a complex task (Carpenter and Georgakakos, 2006; Lerat et al., 2012; Pechlivanidis et al., 2010; Pokhrel and Gupta, 2011) since the number of unknown parameters is magnified; there are higher risks of overparameterization, equifinality, and nonidentifiability issues (Beven, 1993, 1996, 2001; Götzinger and Bárdossy, 2007; Kirchner, 2006). Pokhrel and Gupta (2011) even argued that calibration of spatially distributed parameter fields is impossible, since errors in model structure and data remain larger than the effect of spatial variability.

Here, we deliberately chose to let only the precipitation input vary spatially, while keeping model parameters uniform, in order to focus on the sole impact of spatial variability of precipitation on catchment response. This option is supported by the results of previous studies that reported more improvements in model performance related to the spatial distribution of the rainfall input than the distribution of model parameters (Ajami et al., 2004; Andréassian et al., 2004; Boyle et al., 2001). Thus, the parameters of the semidistributed model were constrained to be the same on all subcatchments. Therefore, only six parameters have to be estimated: the five parameters of the GR5H model and the celerity parameter of the channel-routing method (Table 2). They are calibrated against flow measurements at the outlet of the catchment (no internal information is used). Calibration is renewed for each spatial resolution (lumped, SD64, SD16 and SD04) to overcome the scale-sensitivity of model parameters
(Bárdossy and Das, 2008; Finnerty et al., 1997; Kumar et al., 2013; Samaniego et al., 2010). Investigating the impact of flow simulation at internal points within the catchment was not within the scope of this study and the reader may refer to Lerat et al. (2012) for a detailed discussion on this issue.

Given the small number of model parameters, the steepestdescent local-search procedure used by Editjano et al. (1999) was deemed sufficiently robust to optimize the parameters. It was applied with the Kling-Gupta efficiency (KGE) objective function (Gupta et al., 2009). The initial parameter set to start optimization is determined by a gross pre-sampling of the parameter space using the discrete sampling method proposed by Perrin et al. (2008). This further limits the risk of the procedure being trapped in local optima.

\subsection{Method and criteria for the evaluation of streamflow simulations}

We performed split-sample calibration-validation tests (Klemeš, 1986). The 10 yr study period (1997-2006) was divided into two independent $5 \mathrm{yr}$ subperiods (1997-2001 and 2002-2006). Model parameters were calibrated on the first subperiod and model performance was validated on the second one, and vice versa.

Although the model was continuously run for the periods tested, model performance was evaluated by comparing simulated and observed flow at the outlet of the catchment only for flood events, in order to focus on the periods when rainfall variability has the greatest influence. For each catchment, the 20 largest floods were selected; this lead to a complete 
Table 3. Evaluation criteria used in this study, where $r$ is the Pearson correlation coefficient between the simulated and observed flow, $\beta$ is the ratio between the mean simulated and mean observed flow, $\alpha$ is the ratio between the simulated and observed flow variance, $Q_{j}^{\text {sim }}$ and $Q_{j}^{\text {obs }}$ are, respectively, the simulated and observed discharge at the time steps $j, j_{1}$ and $j_{2}$ the beginning and the end of the flood event. $Q_{\mathrm{p}}^{\text {sim }}$ and $Q_{\mathrm{p}}^{\text {obs }}$ are the simulated and observed peak flow amplitude. $t\left(Q_{\mathrm{p}}^{\text {sim }}\right)$ and $t\left(Q_{\mathrm{p}}^{\text {obs }}\right)$ are the time to the simulated and observed peak flow amplitude, with $t_{\text {beg }}$ and $t_{\text {end }}$ the beginning and the end of the flood event.

\begin{tabular}{llll}
\hline Criteria & Formula & Range & $\begin{array}{l}\text { Error is } \\
\text { null when }\end{array}$ \\
\hline Kling-Gupta efficiency & $\mathrm{KGE}=1-\sqrt{(r-1)^{2}+(\alpha-1)^{2}+(\beta-1)^{2}}$ & {$[-\infty ; 1]$} & KGE $=1$ \\
Peak flow error & $\Delta Q_{\mathrm{p}}=\frac{\left|Q_{\mathrm{p}}^{\text {sim }}-Q_{\mathrm{p}}^{\text {obs }}\right|}{Q_{\mathrm{p}}^{\text {obs }}}$ & {$[0 ;+\infty]$} & $\Delta Q_{\mathrm{p}}=0$ \\
Time to peak error & $\Delta t_{\mathrm{p}}=\frac{\left|t\left(Q_{\mathrm{p}}^{\mathrm{obs}}\right)-t\left(Q_{\mathrm{p}}^{\text {sim }}\right)\right|}{t_{\text {end }}-t_{\text {beg }}}$ & {$[0 ;+\infty]$} & $\Delta t_{\mathrm{p}}=0$ \\
& $\Delta V=\frac{\sum_{j=j_{1}}^{j_{2}}\left|Q_{j}^{\text {sim }}-Q_{j}^{\text {obs }}\right|}{\sum_{j=j_{1}}^{j_{2}} Q_{j}^{\text {obs }}}$ & {$[0 ;+\infty]$} & $\Delta V=0$ \\
& & &
\end{tabular}

set of 3620 events (181 catchments $\times 20$ events) representing a wide variety of floods. The flood events were automatically selected using the following procedure: (1) the maximum discharge is found, (2) the beginning (end) of the event is defined when the previous (next) discharge is lower than a threshold discharge and (3) if the precipitation is not null at the beginning of the event previously defined, then the beginning of the event is the first of the preceding time steps at which the precipitation is null. The threshold discharge $Q_{0}$ is defined for each event, rising limb, and declining limb of the hydrograph by Eq. (1):

$$
Q_{0}=\max _{\substack{t_{\mathrm{p}-240<t<t_{\mathrm{p}}} \\ t_{\mathrm{p}<t<t_{\mathrm{p}}+240}}}\left(Q_{\mathrm{p}} / 4 ; Q_{\mathrm{m}}+0.05 \cdot\left(Q_{\mathrm{p}}-Q_{\mathrm{m}}\right)\right),
$$

where $Q_{\mathrm{p}}$ is the peak flow (i.e., the maximum discharge found), $t_{\mathrm{p}}$ is the time step at which the peak flow is observed, $Q_{\mathrm{m}}$ is the minimum discharge observed over the 10-day period before (after) the peak flow to calculate the threshold discharge needed to define the beginning (end) of the event.

Table 3 presents the four event-based performance criteria used for the evaluation. The Kling-Gupta efficiency (KGE) (Gupta et al., 2009) measures the overall fit between simulated and observed flows. The peak flow, time to peak and volume errors evaluate the quality of the model simulation on the peak discharge value, timing of the peak discharge and total flow volume of the event, respectively. Note that the peak flow was defined as the maximum discharge, so there was only one peak flow for each event; if several peak flows occurred for the same event, only the highest peak flow was considered for the evaluation.

The relative performance index $R_{\mathrm{m}}[b \mid a]$ formulated by Lerat et al. (2012) is used to compare the performance of modeling option $b$ to modeling option $a$ :
$R_{\mathrm{m}}[b \mid a]=\frac{m\left[Q^{\mathrm{obs}}, Q^{a}\right]-m\left[Q^{\mathrm{obs}}, Q^{b}\right]}{m\left[Q^{\mathrm{obs}}, Q^{a}\right]+m\left[Q^{\mathrm{obs}}, Q^{b}\right],}$

where $m$ is a metric measuring the discrepancies between the simulated and observed streamflows, which ranges between 0 and infinity (with $m=0$ when the error is null), $Q^{a}$ and $Q^{b}$ are, respectively, the discharge computed by the models (or the spatial resolution inputs) $a$ and $b$. The $R_{\mathrm{m}}[b \mid a]$ criterion is bounded between -1 and 1 ( $m=0$ when the error is null), which limits the comparison problems on large sets of catchments arising from the of use of nonbounded criteria, as discussed by Mathevet et al. (2006), Schaefli and Gupta (2007) and Seibert (2001). Table 4 details the interpretation of $R_{\mathrm{m}}$.

\subsection{Criteria for the evaluation of rainfall spatial variability}

We used two indexes to quantify and compare the spatial variability of precipitation fields: the index of spatial rainfall variability, $I_{\sigma}$, and the location index, $I_{L}$, proposed by Smith et al. (2004) and shown in Eqs. (3) and (4) respectively. In addition, we used the catchment-scale storm velocity, $V_{S}$, proposed by Zoccatelli et al. (2011) to compute the rainfall movement index of precipitation fields, $I_{\mathrm{M}}$, shown in Eq. (5).

$I_{\sigma}=\frac{\sum_{t=1}^{T} \sigma_{t} \cdot P_{t}}{\sum_{t=1}^{T} P_{t}}$
$I_{\mathrm{L}}=\frac{\sum_{t=1}^{T} I_{\mathrm{pcp}}(t) \cdot P_{t}}{\sum_{t=1}^{T} P_{t}}$ 
Table 4. Interpretation of the relative performance index $R_{m}[b \mid a]$ comparing the performance of model $b$ to the reference model $a$ using a metric $m$ (Lerat et al., 2012).

\begin{tabular}{lll}
\hline$R_{\mathrm{m}}[b \mid a]$ & $m\left(Q^{\mathrm{obs}}, Q^{a}\right) / m\left(Q^{\mathrm{obs}}, Q^{b}\right)$ & Interpretation \\
\hline 1 & 0 & Model $a$ is perfect according to the metric $m$, with $m\left[Q^{\text {obs }}, Q^{a}\right]=0$ \\
0.5 & $1 / 3$ & $m\left[Q^{\mathrm{obs}}, Q^{a}\right]$ is three times smaller (better) than $m\left[Q^{\text {obs }}, Q^{b}\right]$ \\
0 & 1 & Models $a$ and $b$ are equal to $m\left[Q^{\text {obs }}, Q^{a}\right]=m\left[Q^{\text {obs }}, Q^{b}\right]$ \\
-0.5 & 3 & $m\left[Q^{\text {obs }}, Q^{a}\right]$ is three times larger (worse) than $m\left[Q^{\text {obs }}, Q^{b}\right]$ \\
-1 & $+\infty$ & Model $b$ is perfect according to the metric $m$, with $m\left[Q^{\text {obs }}, Q^{b}\right]=0$ \\
\hline
\end{tabular}

$I_{\mathrm{M}}=\frac{\sum_{t=1}^{T} V_{\mathrm{S}}(t) \cdot P_{t}}{\sum_{t=1}^{T} P_{t}}$

In addition to Eqs. (3), (4) and (5), we also have

$\sigma_{t}=\sqrt{\frac{\sum_{i=1}^{N}\left[P_{i}(t)\right]^{2}}{N}-\frac{\left[\sum_{i=1}^{N} P_{i}(t)\right]^{2}}{N^{2}}}$,

$I_{\mathrm{pcp}}(t)=\frac{C_{\mathrm{pcp}}(t)}{C_{\mathrm{bsn}}}$

$C_{\mathrm{pcp}}(t)=\frac{\sum_{i=1}^{N} P_{i}(t) \cdot A_{i} \cdot L_{i}}{\sum_{i=1}^{N} P_{i}(t) \cdot A_{i}}$,

$C_{\mathrm{bsn}}=\frac{\sum_{i=1}^{N} A_{i} \cdot L_{i}}{\sum_{i=1}^{N} A_{i}}$,

$V_{\mathrm{s}}(t)=C_{\mathrm{bsn}} \frac{\mathrm{d} I_{\mathrm{pcp}}(t)}{\mathrm{d} t}$,

where $\sigma_{t}$ is the standard deviation of the hourly precipitation field covering the basin, $P_{i}(t)$ is the hourly rainfall data for the pixel $i$ at the time step $t, N$ is the total number of rainfall pixels within the watershed, $C_{\mathrm{bsn}}$ is the basin's center of mass, $C_{\mathrm{pcp}}(t)$ is the center of rainfall mass for each time step $t, I_{\mathrm{pcp}}(t)$ is the rainfall centroid ratio for each time step $t, A_{i}$ is the pixel area $\left(A_{i}=1 \mathrm{~km}^{2}\right.$ in the present case $)$ and $L_{i}$ is the hydraulic distance between the pixel $i$ and the catchment outlet calculated through the river network.

The spatial rainfall variability, the rainfall localization and the storm movement indexes are computed over the hourly gridded $(1 \times 1 \mathrm{~km})$ rainfall database for each entire flood event. The spatial rainfall variability index $I_{\sigma}$ ranges from 0 to infinity; small values indicate that the spatial variability of the observed rainfall field is low (typical of stratiform events), while high values indicate high spatial variability (convective events). Values of the location index $\left(I_{\mathrm{L}}\right)$ that are less than 1 indicate that the largest rainfall amount measured over the event was generally located at the region closest to the outlet, whereas the values greater than 1 indicate that the center of rainfall is far from the outlet. $I_{\mathrm{L}}$ values close to 1 indicate that the rainfall and basin centroids coincide.

The rainfall movement index $I_{\mathrm{M}}$ quantifies the averaged catchment-scale storm velocity over the flood event duration; it is a velocity measure expressed in $\mathrm{L} \mathrm{T}^{-1}$. As discussed by Zoccatelli et al. (2011), negative and positive values of the rainfall movement index, respectively, indicate that the precipitation field mainly moved to the upstream and the downstream part of the catchment. Null $I_{\mathrm{M}}$ values indicate that the storm is stationary or moved to the upstream as well as downstream part of the catchment during the flood event duration.

\section{Results and discussion}

\subsection{Typology of the 3620 observed flood events}

The distribution of characteristics of the 3620 observed flood events are presented in Fig. 6. The spatial representations shown in Fig. 7 use values averaged over the 20 events selected for each catchment. About $5 \%$ of the events are longer than $490 \mathrm{~h}$ (20 days); these events are observed in catchments with dominant groundwater contributions, mainly located in northern France (Fig. 7). The mean rainfall amounts on the event scale vary between 1 and $500 \mathrm{~mm}$ over the 181 catchments, with a mean value equal to $72 \mathrm{~mm}$ (Fig. 6). The rainfall amounts greater than $300 \mathrm{~mm}$ are observed for 32 events with generally short duration (less than $138 \mathrm{~h}$ ), which are typical of late summer Mediterranean conditions (Fig. 7). The highest peak flow value is observed in the Massane at Argelès-sur-Mer $\left(16 \mathrm{~km}^{2}, \max \left(Q_{\mathrm{p}}\right)=36.7 \mathrm{~mm} \mathrm{~h}^{-1}\right)$, which is the smallest catchment in the catchment set. Peak flows greater than $4 \mathrm{~mm} / \mathrm{h}$ are observed for 111 flood events (3\% of events), which all occurred in the Cévennes and Mediterranean regions: in the Ardèche at Meyras $\left(99 \mathrm{~km}^{2}\right.$, $\left.\max \left(Q_{\mathrm{p}}\right)=11.3 \mathrm{~mm} \mathrm{~h}^{-1}\right)$, the Gardon at Mialet $\left(244 \mathrm{~km}^{2}\right.$, 

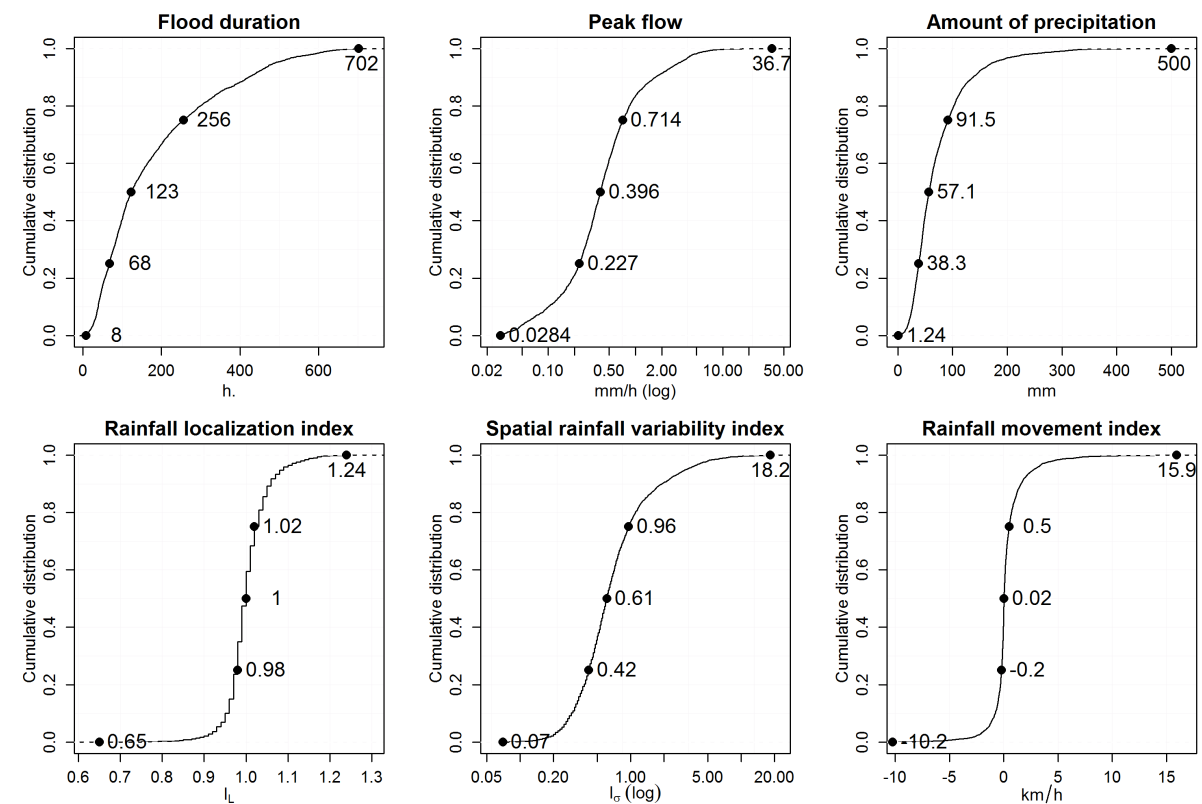

Fig. 6. Cumulative distribution of flood durations, peak values, event-based amounts of precipitation, localization, spatial variability and rainfall movement indexes of precipitation fields for the 3620 observed events in the 181 selected catchments (values for the minimum, 25 th, 50th, and 75th percentiles, and the maximum are indicated on the cumulative distribution axes).
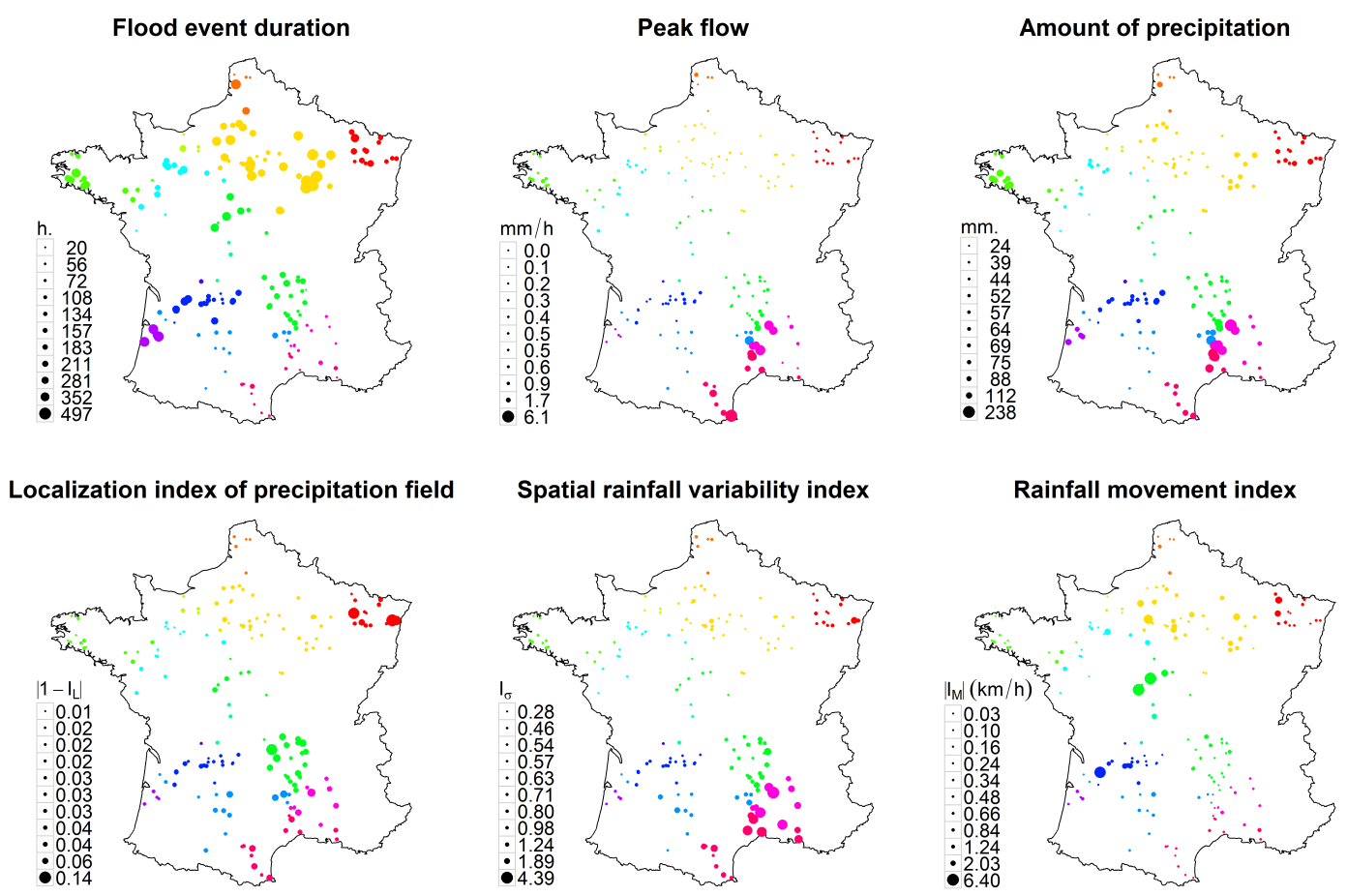

Fig. 7. Event characteristics averaged over the 20 flood events observed in each of the 181 catchments. The peak flow coefficient is the ratio between the peak flow and the mean flow. The colors refer to geographic regions.

$\left.\max \left(Q_{\mathrm{p}}\right)=10.7 \mathrm{~mm} \mathrm{~h}^{-1}\right), \ldots$, and the Hérault at Gignac $\left(1430 \mathrm{~km}^{2}, \max \left(Q_{\mathrm{p}}\right)=4.3 \mathrm{~mm} \mathrm{~h}^{-1}\right)$.

The median value of the location index is almost equal to 1 , which indicates that events are equally distributed between events closer to or farther from the outlet than the catchment centroid. The spatial rainfall variability index is quite low (the third quartile is less than 1), which means that the precipitation fields in the 3620 observed events are generally stratiform or spatially uniform (Fig. 6). Nevertheless, the spatial rainfall variability index is greater than 1.11 for $20 \%$ 

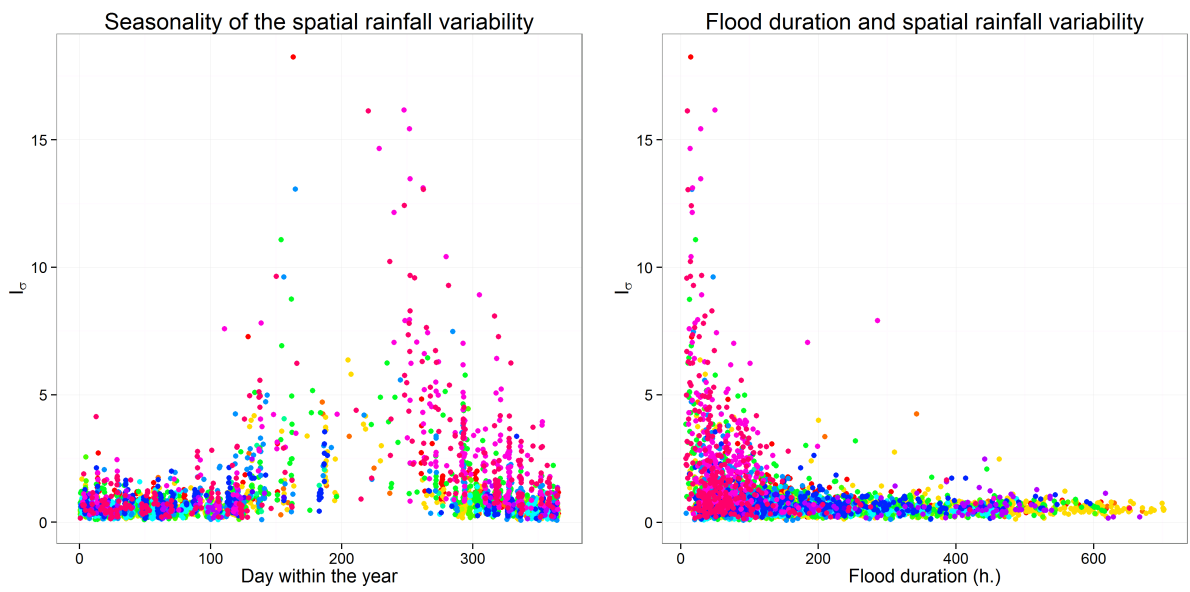

Fig. 8. Relationship between seasonality of the spatial rainfall variability (left panel) and spatial rainfall variability and event duration (right panel) for the 3620 flood events observed. The colors refer to geographic regions, with the same color scheme used in Fig. 7.

of the events, which means that the data set has a significant number of high-variability events (Fig. 6).

The localization index is correlated to the spatial rainfall variability index: values far from 1 are usually observed in the regions where high values of the spatial rainfall variability index are also observed (Fig. 7). Indeed, precipitation fields localized close to (or far from) the outlet are most likely to be observed in regions where precipitation fields are spatially variable. In addition, extreme values of the localization index are also observed in northeastern France, where the largest catchments of the set are located: these large catchments are more exposed to high localization indices (i.e., with precipitation fields centered on the upstream part of the catchment) because of the orographic effect.

The rainfall movement index ranges between -10.2 and $15.9 \mathrm{~km} \mathrm{~h}^{-1}$ but the values are generally low for the 3620 flood events: the 5 th and 95 th percentiles are -1.47 and $2.78 \mathrm{~km} \mathrm{~h}^{-1}$ respectively (Fig. 6). Similar results have been reported by Tarolli et al. (2013) for 10 subcatchments located in the Eastern Ore Mountains in the Czech Republic. Note that the rainfall movement indexes are catchment-scale storm velocities, which are not comparable to the velocities of storm elements (Tarolli et al., 2013). The highest absolute values averaged over 20 flood events selected for each catchment (Fig. 7) are observed in the Sauldre catchment $\left(I_{\mathrm{M}}=6.39 \mathrm{~km} \mathrm{~h}^{-1}\right)$ in Selles-sur-Cher $\left(2296 \mathrm{~km}^{2}\right)$, the Indre catchment $\left(I_{\mathrm{M}}=6.20 \mathrm{~km} \mathrm{~h}^{-1}\right)$ in Saint-Cyran-du-Jambot $\left(1706 \mathrm{~km}^{2}\right)$ and the Isle catchment $\left(I_{\mathrm{M}}=6.15 \mathrm{~km} \mathrm{~h}^{-1}\right)$ in Abzac $\left(3757 \mathrm{~km}^{2}\right)$. These catchments have low elevations (lower than 434, 500 and $560 \mathrm{~m}$ respectively) and narrow and elongated shapes with west-east orientations similar to the main atmospheric fluxes from the Atlantic Ocean.

The precipitation fields with a strong spatial variability have short durations (Fig. 8), and they are typically observed between May and October (Fig. 8) in the Mediterranean area (Fig. 7). The largest peak flow coefficients are also observed in the Mediterranean area, where the catchments are exposed to summer convective storms with high spatial variability of precipitation fields (Fig. 7). The highest values are obtained in the Ardèche catchment $\left(I_{\sigma}=4.39\right)$ at Vogüe $\left(625 \mathrm{~km}^{2}\right)$, and in the Hérault catchments and the Gardon catchments $\left(I_{\sigma}>3.5\right)$, which are all located in the Mediterranean area (Fig. 7).

\subsection{Impact of spatial rainfall resolution on streamflow simulation efficiency}

The impact of spatial rainfall resolution inputs on flow simulation was investigated by comparing model simulations for the four spatial resolutions: (1) lumped, (2) $64 \mathrm{~km}^{2}$ (SD64), (3) $16 \mathrm{~km}^{2}$ (SD16) and (4) $4 \mathrm{~km}^{2}$ (SD04). The results were analyzed by catchment classes based on the catchments' characteristics, shown in Table 1. The catchment area and the rainfall intensity coefficient were found to be the most relevant in explaining the impact of spatial rainfall resolution on model performance.

Figure 9 presents model performance by catchment classes based on catchment area: the catchment set is divided into three subsamples of 60 catchments (one subsample having 61 catchments). The size ranges from 16 to $155 \mathrm{~km}^{2}$ for the G01 group of the smallest catchments, and from 497 to $6834 \mathrm{~km}^{2}$ for the G03 group of the largest catchments (Fig. 9). Note that for G01, only the smaller subcatchment size $\left(4 \mathrm{~km}^{2}\right)$ could be tested for all catchments. Therefore, the results for the two other resolutions are not shown.

Some obvious modeling results can be observed in Fig. 9:

1. Model performance is higher for the largest catchments (see, e.g., Merz et al., 2009). Significant differences were found in model efficiency between the smallest-catchment group (G01; $\left.\Delta Q_{\mathrm{p}}=37 \%, \Delta V=26 \%, \Delta t_{\mathrm{p}}=0.14, \quad \mathrm{KGE}=0.44\right)$ 

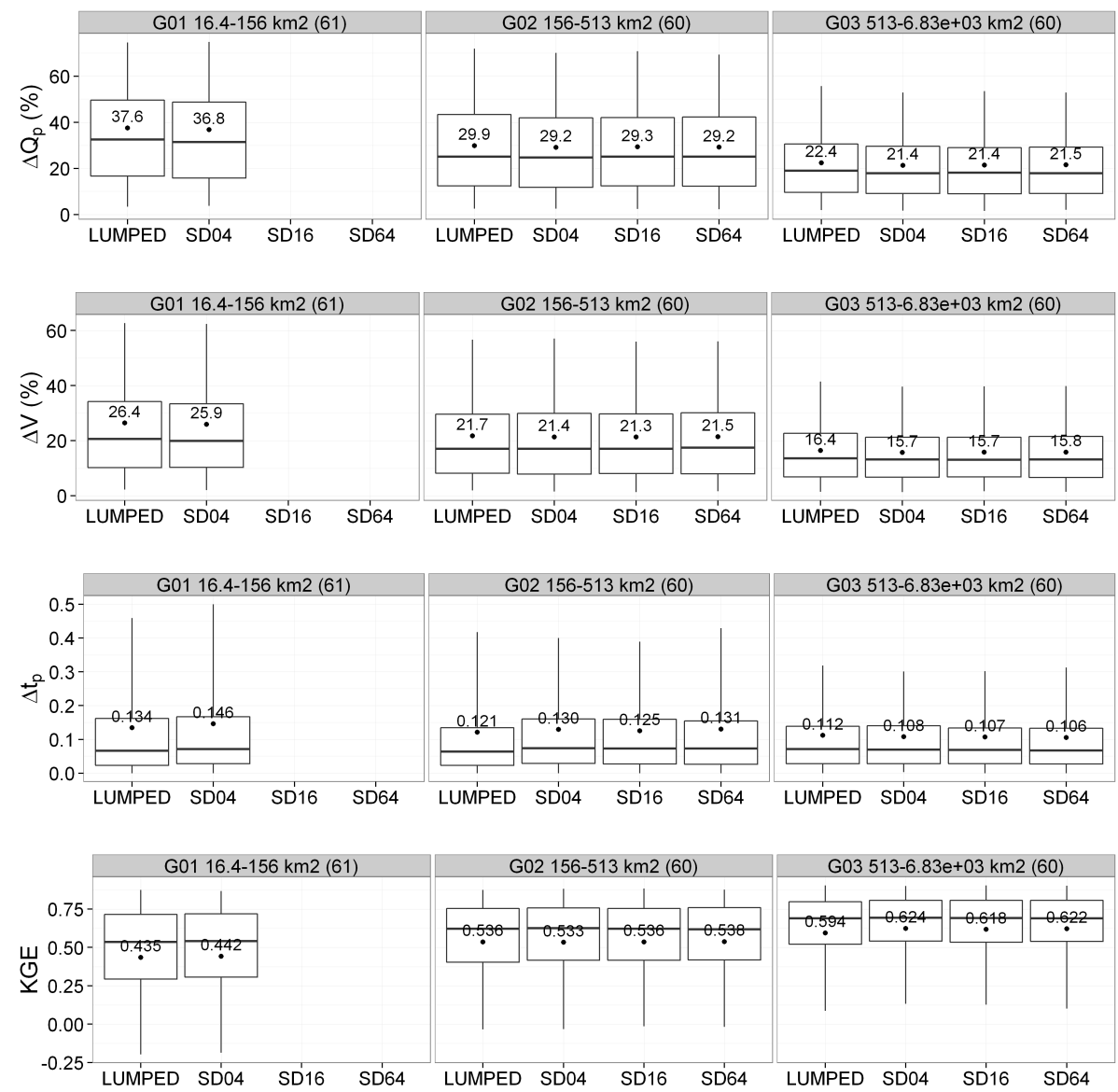

Fig. 9. Distributions of model performance in validation mode using the four efficiency criteria (top to bottom panels) for three catchment groups (G01, G02, and G03, left to right panels) sorted by increasing catchment area. Model performance was computed for 3620 flood events and for different spatial resolutions of precipitation forcing (LUMPED, SD64, SD16 and SD04). The box plots show the 5th, 25th, 50th, 75th, and 95th percentiles, and the mean value is given and shown by a dot.

and the largest-catchmentgroup $\left(\mathrm{G} 04 ; \Delta Q_{\mathrm{p}}=21 \%\right.$, $\left.\Delta V=16 \%, \Delta t_{\mathrm{p}}=0.11, \mathrm{KGE}=0.60\right)$.

2. The KGE criteria followed identical trends as the three event-based criteria $\Delta Q_{\mathrm{p}}, \Delta t_{\mathrm{p}}$ and $\Delta V$. This may be due to the fact that KGE is balanced between the bias (e.g., volume of flow), the relative variability in the simulated and observed values (i.e., the spread of flow) and the coefficient of correlation (i.e., the timing and shape of the hydrograph) (Gupta et al., 2009).

3. For all catchment subsets, the lumped model performs almost as well as the semidistributed model, regardless of the spatial resolution of precipitation input. Only slight improvements were noted with higher spatial resolution in precipitation inputs and they were larger for the largest-catchment subsample (group G03). Similar conclusions were made by Arnaud et al. (2011), for example. In the present study, the KGE averaged over 1200 flood events (for the 60 largest catchments) rose from 0.594 for the lumped model to 0.624 for the semidistributed model with the finest resolution; the averaged absolute volume, peak and time to peak errors decreased from 22.4 to $21.4 \%$, from 16.4 to $15.7 \%$, and from 0.112 to 0.108 , respectively (Fig. 9).

In Fig. 10, model performance is analyzed by catchment classes based on catchment area and the rainfall intensity coefficient. Each catchment subsample (based on catchment area) is divided into three subclasses based on the rainfall intensity coefficient (Table 1). Each subclass has the same number of catchments (20 catchments) except one having 21 catchments (G01 and low rainfall intensity coefficient). The low rainfall intensity coefficients range from 17.3 to 19.4 for G01, from 16.8 to 19.0 for G02 and from 14.3 to 18.0 for G03. The high rainfall intensity coefficients range from 21.6 to 27.7 for G01, from 20.9 to 28.3 for G02, and from 19.3 to 25.4 for G03. Note that the rainfall intensity coefficient (Table 1) was calculated over the whole period of records (1997-2006) and was not limited to the selected events (we consider this coefficient as a catchment descriptor). 


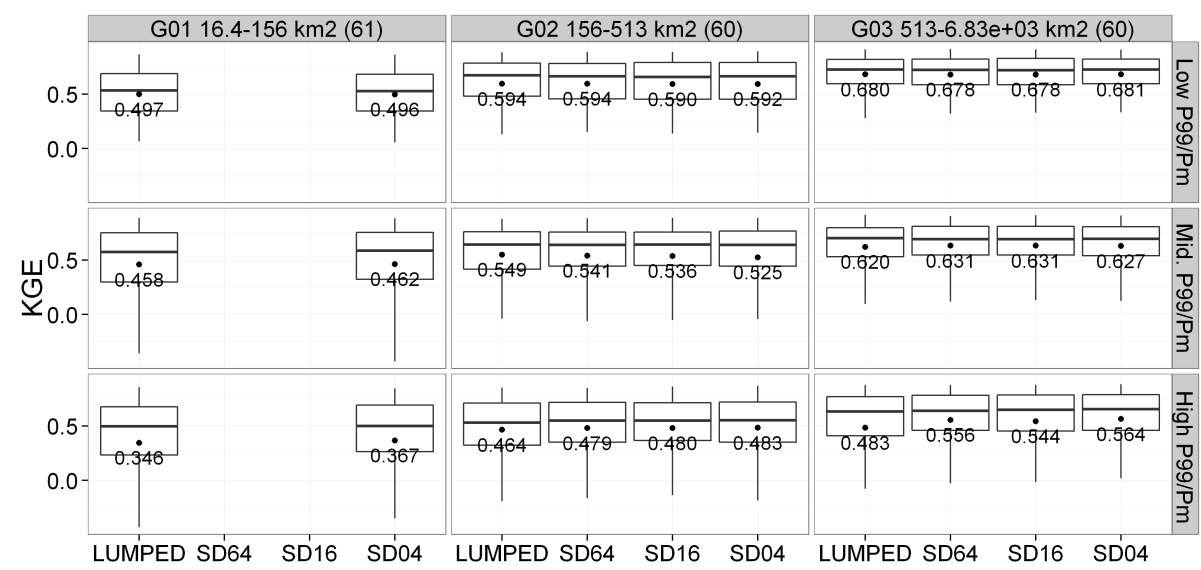

Fig. 10. Distributions of model performance in validation mode for three catchment groups sorted by increasing catchment area (G01, G02, and G03, left to right panels) and by increasing rainfall intensity coefficient (low, intermediate and high $P_{99} / P_{\mathrm{m}}$; top to bottom panels). The model performance was computed for 3620 flood events and for different spatial resolutions of precipitation forcing (LUMPED, SD64, SD16 and SD04). The box plots show the 5th, 25th, 50th, 75th, and 95th percentiles, and the mean value is shown by a dot.

Model performance was better for catchments with a low rainfall intensity coefficient for all catchment area groups (Fig. 10). Significant differences were found in model efficiency, which decreased when the rainfall intensity coefficient rose: on average, between the low and high rainfall intensity coefficient, the KGE criteria ranged from 0.49 to 0.35 for the smallest-catchment group, and from 0.68 to 0.48 for the largest-catchment group (Fig. 10).

The lumped model performed as well as the semidistributed model regardless of the spatial resolution of precipitation input for catchments with a low rainfall intensity coefficient. Interestingly, improvements were noted with higher spatial resolution in precipitation inputs for catchments with a high rainfall intensity coefficient $\left(P_{99} / P_{\mathrm{m}}>20\right)$ and for all ranges of catchment area (Fig. 10). Although model performance improvements were slight for the G01 (16$\left.156 \mathrm{~km}^{2}\right)$ and G02 (156-513 km²) catchment groups, significant improvements were obtained for the largest-catchment group (G03: $\left.513-6834 \mathrm{~km}^{2}\right)$ : the KGE averaged over 20 flood events (for the 20 largest catchments with a high rainfall intensity coefficient) rose from 0.483 for the lumped model to 0.564 for the semidistributed model with the finest resolution.

Regardless of the catchment area and rainfall intensity coefficient, the semidistributed model performed equally well at the different spatial resolutions investigated (SD64, SD16 and SD04). Indeed, the improvements in streamflow simulation at the catchment outlet between the lumped model and the semidistributed model at the finest spatial resolution (SD04) were nearly equivalent at coarser spatial resolutions (SD16 and SD64) (Fig. 10).

These results allow us to generalize, with confidence, the conclusions drawn by previous studies (but only obtained over a few catchments) that reported a lack of significant differences between lumped and semidistributed flow simulations at the catchment outlet (Ajami et al., 2004; Apip et al., 2012; Bell and Moore, 2000; Lindström et al., 1997; Naden, 1992; Nicòtina et al., 2008; Obled et al., 1994; Refsgaard and Knudsen, 1996). However, we found that the impact of higher resolution in precipitation inputs were catchment-dependent since the quality of streamflow simulations was significantly improved at the outlet of catchments exposed to high rainfall intensity, and these improvements rose with catchment area.

\subsection{Do criteria describing rainfall spatial variability explain the observed differences?}

The previous results were averaged over the 20 flood events for each catchment; this may hide some of the model behavior variability between events, depending on the characteristics of the precipitation fields. This aspect is now further investigated. Given the very limited differences between the three sizes of subcatchments, hereafter we will only consider the lumped and semidistributed (SD04, finest resolution) simulations. Figure 11 shows the links between the relative performance index (see Eq. 5) applied using the KGE criterion (here noted $R_{1-\mathrm{KGE}}$ ) and the indexes of rainfall variability (location index $I_{L}$ and spatial rainfall variability index $I_{\sigma}$ ) and rainfall movement $\left(I_{\mathrm{M}}\right)$. A positive $R_{1-\mathrm{KGE}}$ criterion indicates that the semidistributed approach is better than the lumped one, and the reverse is true for negative values.

First of all, it is worth noting that flood events with strong spatial variability of precipitation rarely occur compared to stratiform storms with uniform precipitation fields; most of the $I_{\mathrm{L}}$ values are close to 1 , and $I_{\sigma}$ values are generally low (Fig. 11). Interestingly, the median $I_{\mathrm{L}}$ value rises with catchment area from 0.97 for the smallest-catchment group (G01) to 0.99 for the medium-sized catchment group (G02), and up 

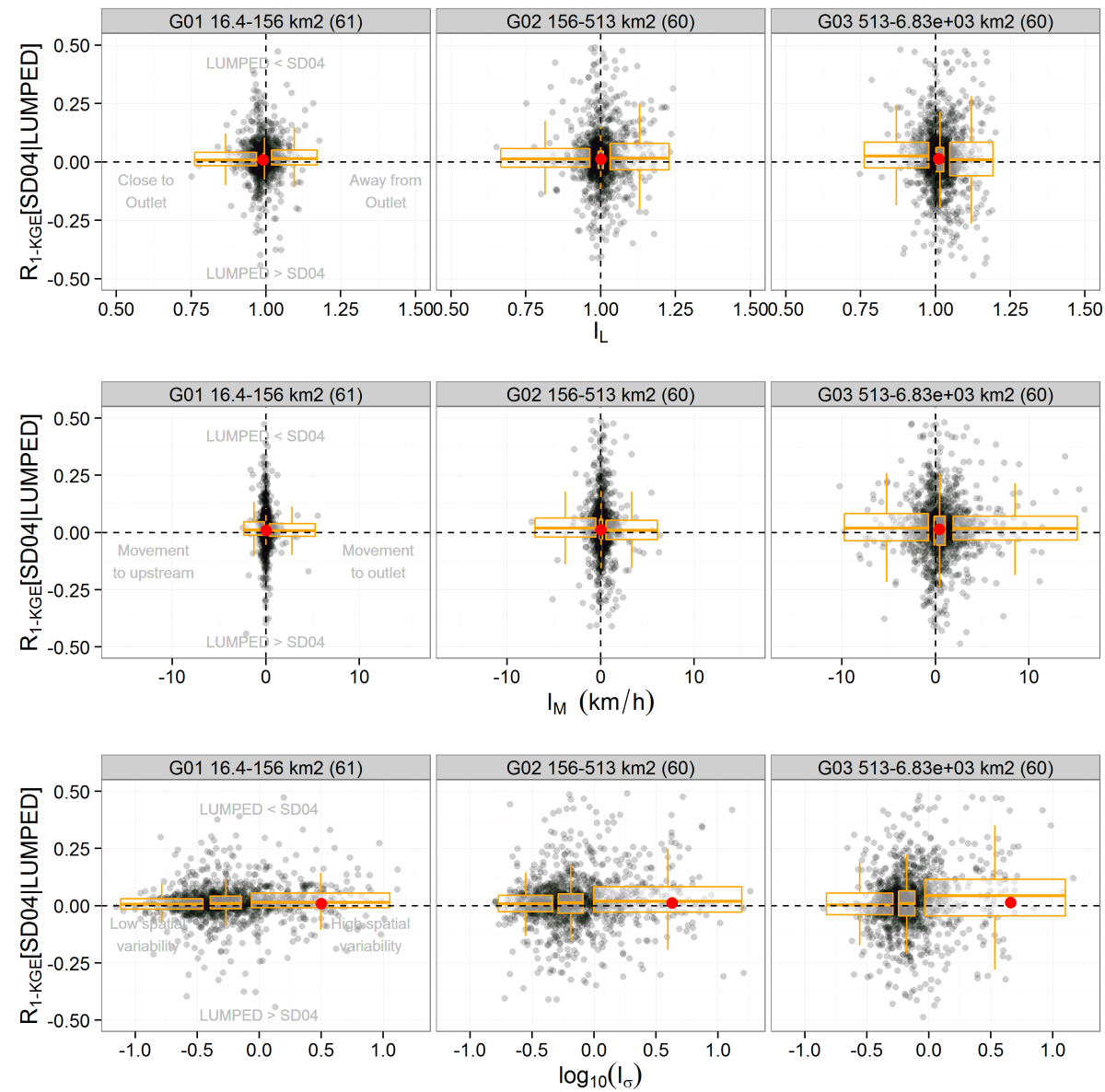

Fig. 11. Relative KGE performance index in validation mode between the lumped and the semidistributed (SD04) simulations. The relative performance indexes are computed for 3620 flood events ordered by location index (top panels), rainfall movement index (middle panels), spatial rainfall variability index (bottom panels) and for three groups of 60 catchments classed by area (G01, G02, and G03). For each catchment group, the red point plotted on the $x$ axis at $x=0$ shows the median values of the variable of interest $\left(I_{\mathrm{L}}, I_{\mathrm{M}}\right.$ or $\left.I_{\sigma}\right)$. The box plots show the distribution of the relative KGE performance index for three groups of events with the same number of events per box plot.

to 1.01 for the largest-catchment group (G03). Similarly, the median $I_{\sigma}$ value rises with catchment area from 0.52 to 0.66 and to 0.69 for the G01, G02, and G03 catchment groups, respectively. Thus, the precipitation centroid is generally located at the upstream part of the basin for large catchments, and the probability of obtaining uniform spatial rainfall fields is lower in large catchments.

The rainfall movement index increased with catchment size (Fig. 11); most of the $I_{M}$ values are close to 0 for the smallest-catchment group (G01) whereas the highest values are observed for the group of largest catchments (G03). This result corroborates the findings reported by Tarolli et al. (2013) who assessed the catchment-size dependency of storm velocity. Nevertheless, the catchment-scale storm velocity and the rainfall motion do not seem to explain the impact of spatial resolution input on streamflow simulation quality; the semidistributed rainfall-runoff model could obtain better as well as worse performance than the lumped model for all catchment groups and all ranges of rainfall movement index (Fig. 11).

For the small-catchment subsamples (groups G01 and G02: from 16 to $513 \mathrm{~km}^{2}$ ), the semidistributed model (with high spatial resolution of precipitation inputs) and the lumped model (with spatially uniform precipitation inputs) performed equally well (Fig. 11). For the largest catchments (group G03: from 513 to $6834 \mathrm{~km}^{2}$ ), the results were mixed for low spatial rainfall variability and location indexes close to and greater than 1 (Fig. 11).

Nevertheless, for the largest catchments (group G03: from 513 to $6834 \mathrm{~km}^{2}$ ), the semidistributed model with high spatial resolution yields better streamflow simulations for the few flood events in which the greatest spatial variability in precipitation fields are observed (high $I_{\sigma}$ values or $I_{\mathrm{L}}<1$ ) (Fig. 11). Interestingly, the semidistributed model performed better than the lumped model (for large catchments) for the events where the precipitation fields were located close to the outlet $\left(I_{\mathrm{L}}<1\right)$, while the lumped model was able to cope 

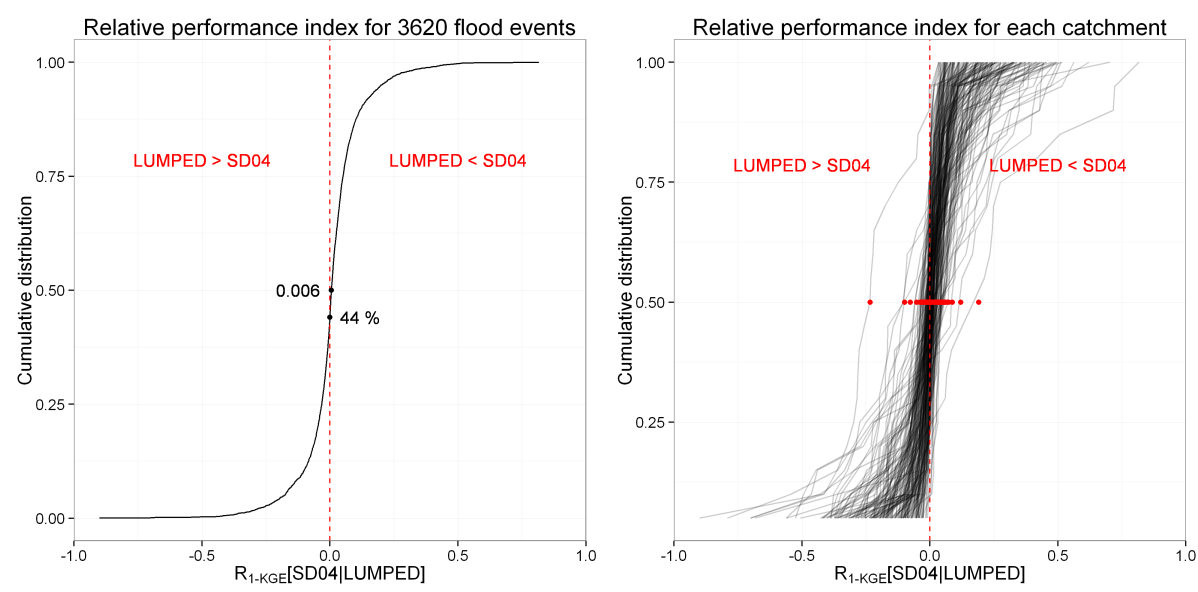

Fig. 12. Distribution of relative performance index values in validation mode of the lumped model and the SD04 semidistributed model. The distribution is drawn for the whole set of 3620 flood events (left panel) and for the 20 events of each catchment (right panel). The red points show the median values of the relative performance index for each catchment.

with rainfall fields located far from the outlet $\left(I_{\mathrm{L}}>1\right)$. This may be due to the fact that larger precipitation amounts are more often concentrated at the upstream part of the catchment due to an orographic effect and a strong altitudinal gradient in large catchments (Fig. 7). Thus, through calibration, the lumped model acquires the ability to accurately reproduce the catchment response for such more common rainfall field patterns, but not for the other "extraordinary" (from a precipitation spatial variability point of view) events.

These results - based on a large set of catchments (181) and a wide variety of flood events - clearly show that the impact of spatial variability of precipitation is scale-dependent and event-characteristic-dependent, as suggested by several authors (Ajami et al., 2004; Bell and Moore, 2000; Koren et al., 2004; Segond et al., 2007; Smith et al., 2004; Tetzlaff and Uhlenbrook, 2005; Winchell et al., 1998). This may explain why contradictory results can be found in the literature on the impacts of spatial rainfall variability on the catchment response; this study shows that some flood events are improved using higher spatial rainfall information and others are not (Fig. 11).

\subsection{Which catchments should be modeled in a semidistributed way?}

Here we investigate the possibility of identifying catchments where a spatially distributed representation would bring a definite advantage. Figure 12 shows the comparison between lumped and semidistributed simulations evaluated by the relative performance index on KGE for the whole set of catchments (181) (left, overall distribution on the 3620 flood events) and by catchment (right, 181 distributions on 20 flood events each). The analysis based on the 3620 observed flood events shows that the results are contrasting (Fig. 12): $44 \%$ of flood events are better simulated with the lumped model (fed with spatially uniform precipitation inputs). Using higher spatial resolution of precipitation inputs only improves model performance for a small majority $(56 \%)$. It is difficult to draw conclusions given the low median value of the relative performance index (equal to 0.006) (Fig. 12).

However, when the large set of flood events is analyzed by catchment (Fig. 12, right panel), these contrasting results appear to be catchment-dependent: spatial precipitation inputs greatly improve the streamflow simulations at the outlets of some catchments, whereas the impact of spatial forcing is insignificant, or semidistributed modeling is worse than lumped modeling, for other catchments (Fig. 12). These findings highlight the need to test model hypotheses on large and diversified catchment sets (Andréassian et al., 2009).

\subsection{Can specific catchment behaviors be explained?}

To identify the catchments that benefit (or not) from higherresolution rainfall information, the relative performance indexes calculated over 20 flood events (Fig. 12) were averaged by catchment. The cumulative distribution of the mean relative performance index and the geographic localization for the 181 catchments are shown in Fig. 13. The performance of the lumped model was better than that of the semidistributed model for $39 \%$ of catchments. Hence the semidistributed approach appears beneficial for $61 \%$ of the catchment set (Fig. 13).

The analysis applied independently for each catchment pointed out regional tendencies concerning the impact of spatial rainfall resolution on streamflow simulation (Fig. 13). In western France, streamflow simulation at the outlets of the catchments located close to the Atlantic coast were not improved when using higher spatial rainfall information. In this region, catchments are exposed to an oceanic climate with precipitation fields that are spatially quite uniform (Fig. 7), which may explain the fact that the lumped model performed 
Table 5. List of particular catchments shown in Fig. 13.

\begin{tabular}{|c|c|c|c|c|c|c|}
\hline ID & Catchment & $\begin{array}{r}\text { Area } \\
\left(\mathrm{km}^{2}\right)\end{array}$ & $\overline{I_{\sigma}}$ & $\overline{\left|1-I_{L}\right|}$ & $\begin{array}{c}\text { KGE } \\
\text { [LUMPED - SD04] }\end{array}$ & Characteristic \\
\hline 1 & Eyre at Salles & 1678 & 0.77 & 0.03 & $0.645-0.532$ & Implausible spatial precipitation data \\
\hline 2 & Petite Leyre at Belhade & 413 & 0.78 & 0.02 & $0.619-0.417$ & Implausible spatial precipitation data \\
\hline 3 & Orge at Saint-Chéron & 111 & 1.15 & 0.04 & $0.451-0.314$ & Groundwater contribution \\
\hline 4 & Essonne at Boulancourt & 586 & 0.58 & 0.01 & $0.322-0.397$ & Groundwater contribution \\
\hline 5 & Indre at Saint-Cyran-du-Jambot & 1706 & 0.79 & 0.05 & $0.639-0.698$ & Narrow and elongated \\
\hline 6 & Alagnon at Joursac & 322 & 1.14 & 0.05 & $0.444-0.514$ & Particular morphology \\
\hline 7 & Allier at Langogne & 323 & 2.00 & 0.04 & $0.593-0.627$ & High spatial rainfall variability \\
\hline 8 & Gardon at Mialet & 244 & 3.52 & 0.06 & $0.450-0.481$ & High spatial rainfall variability \\
\hline 9 & Hérault at Gignac & 1429 & 3.57 & 0.04 & $0.631-0.712$ & High spatial rainfall variability \\
\hline 10 & Vigueirat at Tarascon & 257 & 4.21 & 0.03 & $0.475-0.515$ & High spatial rainfall variability \\
\hline 11 & Moselle at Custines & 6834 & 1.08 & 0.12 & $0.804-0.819$ & Extreme location index value \\
\hline 12 & Bruche at Holtzheim & 676 & 1.22 & 0.10 & $0.573-0.616$ & Extreme location index value \\
\hline
\end{tabular}

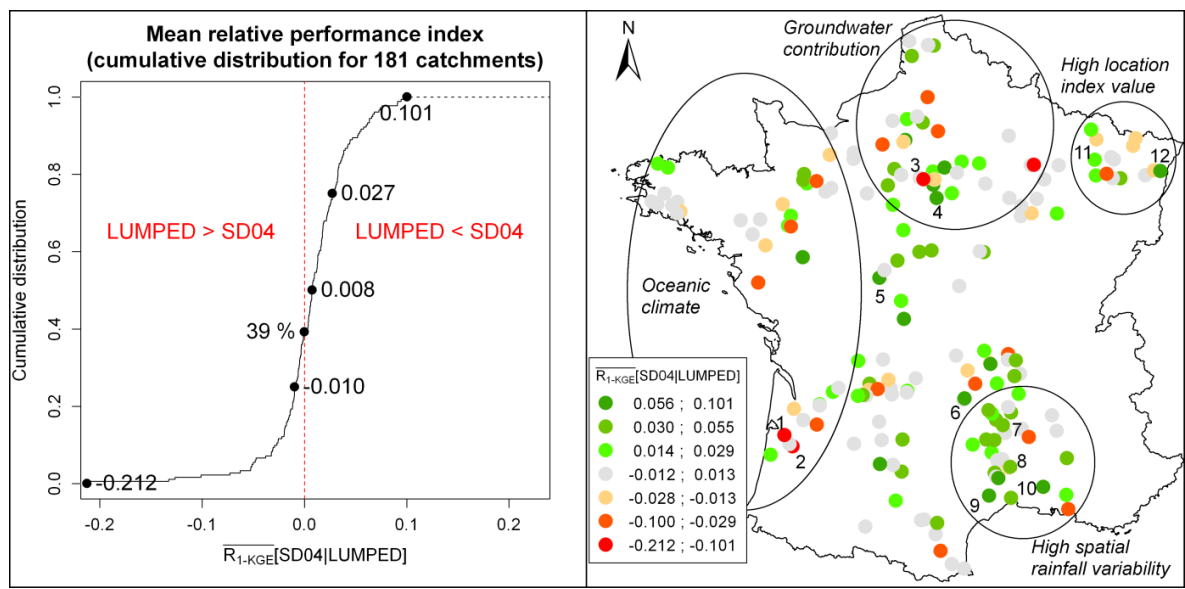

Fig. 13. Relative performance index averaged by catchment: cumulative distribution (left panel); geographic distribution (right panel). The number refers to the particular catchments discussed in Table 4 . Green dots $\left(R_{1-\mathrm{KGE}}>0\right)$ indicate better performances of the semidistributed approach.

as well as the semidistributed model (Fig. 13). Two catchments, the Petite Leyre and the Eyre catchments (Fig. 13 and Table 5), exhibited strong model performance decreases when used in spatial distribution mode. Detailed analysis showed that the semidistributed model was affected by absurdly high values in spatial precipitation data inputs coming from radar measurements (despite the treatments applied to correct them and the numerous quality checks). These inaccurate precipitation values were smoothed by averaging the spatial precipitation data over the catchment in the lumped model. As a result, the lumped model successfully computed the flow at the catchment's outlets, contrary to the semidistributed model.

In northern France, the results were contrasted. In this region, many catchments are influenced by significant groundwater contribution. Model performance remained low for these catchments whatever the spatial distribution (Fig. 13); for example, for the Essonne catchment, the KGE value increased from 0.322 with the lumped model to only 0.397 with the semidistributed model (Table 5). Increasing spatial information in precipitation inputs did not necessarily yield better flow simulations, and strong decreases in model performance could be observed between the lumped and the semidistributed model (Fig. 13 and Table 5). Our interpretation is that (1) spatial rainfall variability is already quite low in this region (Fig. 7), while (2) the impact of spatially variable precipitation is dampened by the high infiltrability in this catchment dominated by subsurface flow (Nicòtina et al., 2008).

The catchments that benefit most from higher spatial resolution of precipitation inputs (Fig. 13) are the catchments in which precipitation fields are identified to be significantly variable in space (Fig. 7). We identified two regions strongly exposed to spatial rainfall variability: the Cévennes and Mediterranean regions in southern France with high spatial rainfall indexes (Fig. 7), and northeastern France with 


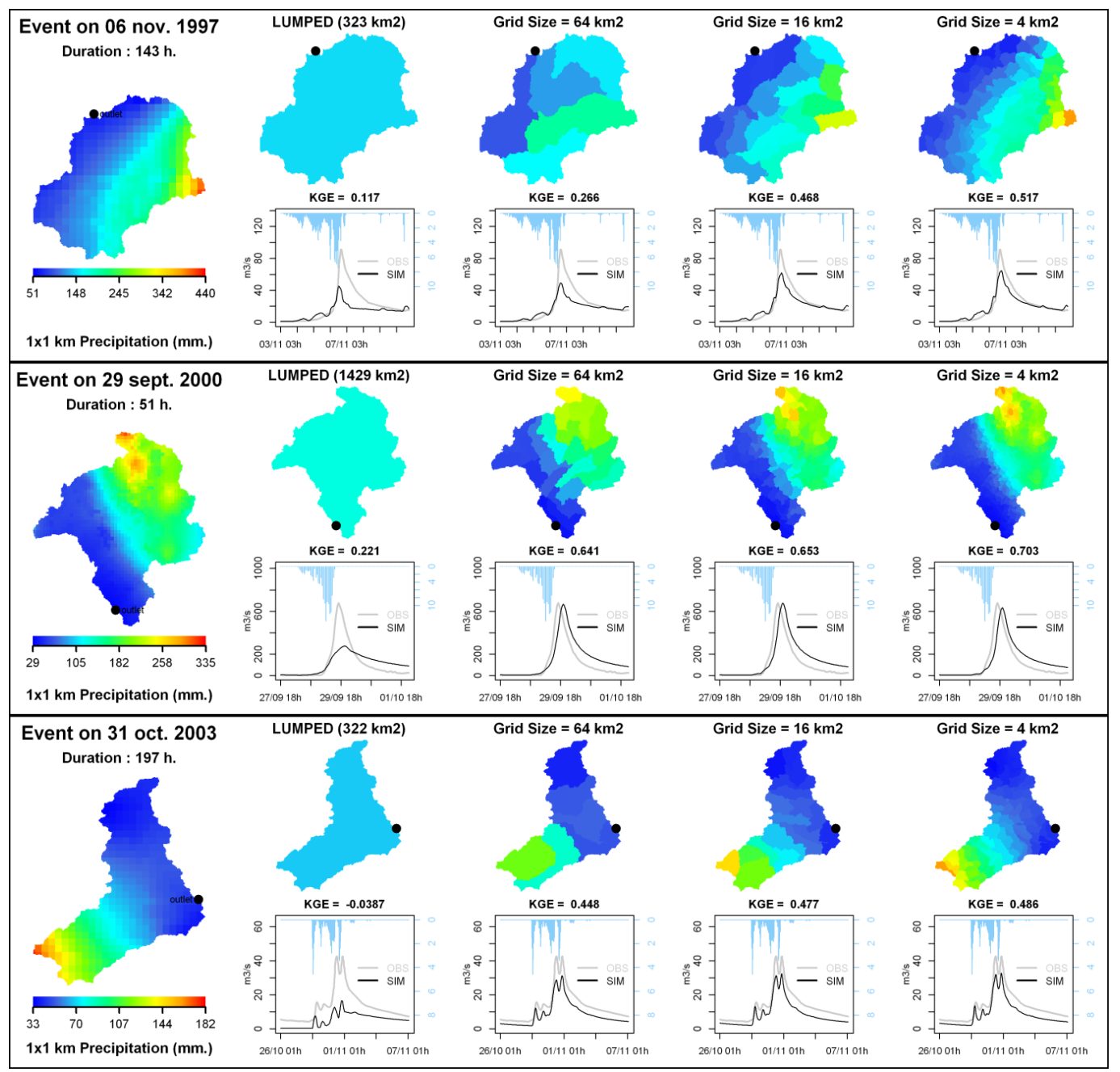

Fig. 14. Cumulated precipitation fields observed in the Cévennes and Mediterranean regions for three flood events with simulated and observed streamflow at different spatial resolutions: November 1997 flood event $\left(I_{\mathrm{L}}=1.08\right.$ and $\left.I_{\sigma}=1.66\right)$ in the Allier catchment at Langogne $\left(323 \mathrm{~km}^{2}\right)$ (top panels); September 2000 flood event $\left(I_{\mathrm{L}}=1.02\right.$ and $\left.I_{\sigma}=6.73\right)$ in the Hérault catchment at Gignac $\left(1429 \mathrm{~km}^{2}\right)(\mathrm{middle}$ panels); October 2003 flood event $\left(I_{\mathrm{L}}=1.05\right.$ and $\left.I_{\sigma}=0.94\right)$ in the Alagnon catchment at Joursac $\left(322 \mathrm{~km}^{2}\right)$ (bottom panels).

extreme location index values (Fig. 7). As examples, we present three flood events with high spatial rainfall variability that occurred in the large Hérault catchment $\left(1430 \mathrm{~km}^{2}\right)$ and the medium-sized Allier $\left(323 \mathrm{~km}^{2}\right)$ and Alagnon catchments $\left(322 \mathrm{~km}^{2}\right)$. The observed precipitation fields were highly variable in space, as indicated by the high values of the spatial rainfall variability index: $I_{\sigma}=6.73$ (September 2000), $I_{\sigma}=1.66$ (November 1997), and $I_{\sigma}=0.94$ (October 2003). As a consequence, the simulated peak flow was well depicted with the semidistributed model due to spatially distributed precipitation inputs, whereas it was missed with spatially uniform precipitation input in lumped modeling (Fig. 14). Similar conclusions were reached for two catchments in northeastern France and one Cévennes catchment where extreme location index values were identified: the quality of streamflow simulations was improved due to higher spatial rainfall information within the semidistributed model (Fig. 15).

\section{Conclusions}

\subsection{Summary}

The impact of higher-resolution rainfall information on streamflow simulation was investigated using a large set of flood events (3620) in 181 French catchments. Semidistributed streamflow simulations were run at different spatial resolutions and evaluated against observed flow data at catchment outlets. The results were analyzed (1) by catchment classes based on catchment area and (2) by flood events based on the spatial variability of observed precipitation fields. 


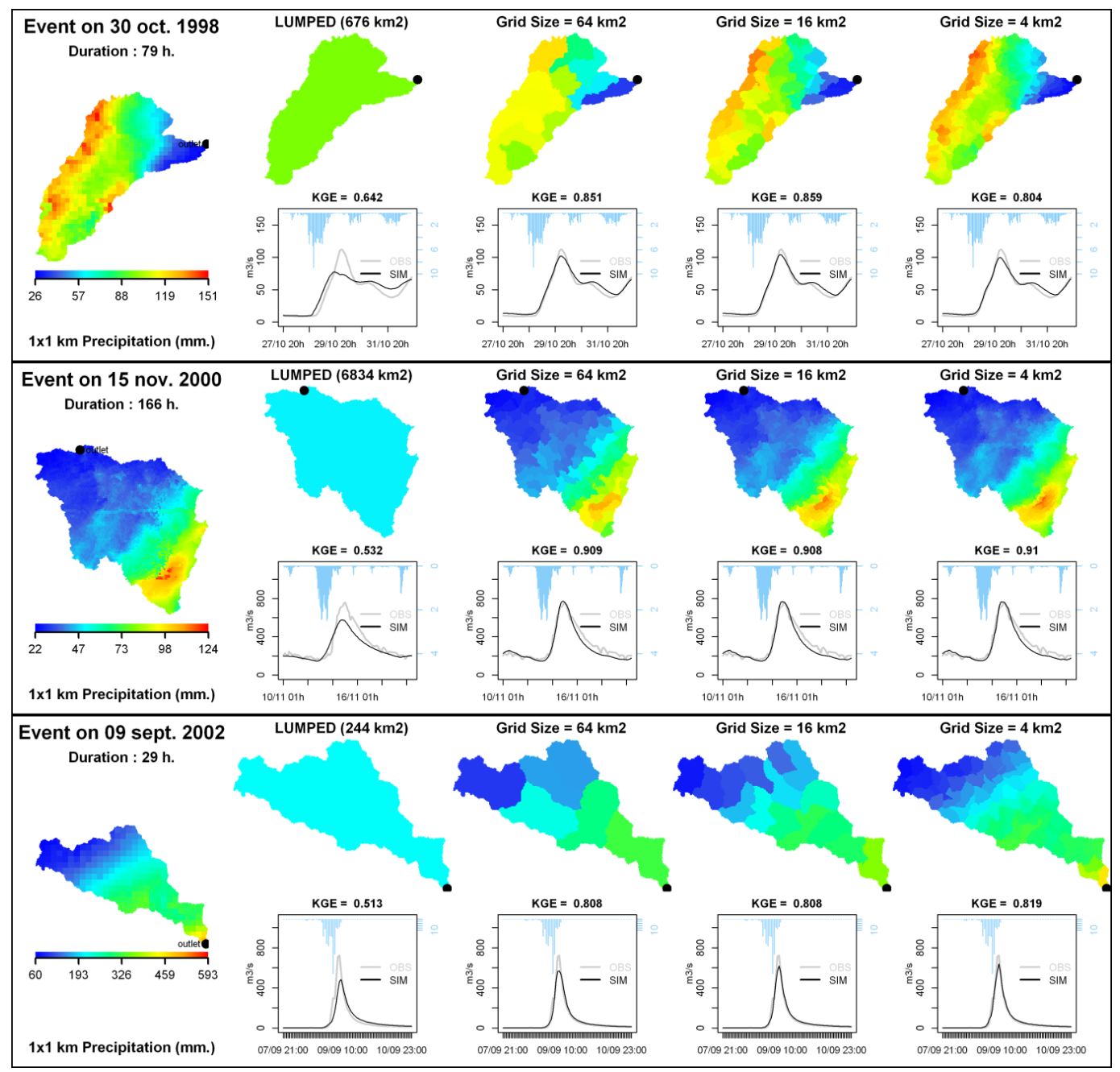

Fig. 15. Cumulated precipitation fields (with extreme location index values) observed for three flood events with simulated and observed streamflow at different spatial resolutions: October 1998 flood event $\left(I_{\mathrm{L}}=1.07\right.$ and $\left.I_{\sigma}=2.00\right)$ in the Bruche catchment at Holtzheim $\left(676 \mathrm{~km}^{2}\right)$ (top panels); November 2000 flood event $\left(I_{\mathrm{L}}=1.12\right.$ and $\left.I_{\sigma}=1.17\right)$ in the Moselle catchment at Custines $\left(6834 \mathrm{~km}^{2}\right)(\mathrm{middle}$ panels); September 2002 flood event $\left(I_{\mathrm{L}}=0.85\right.$ and $\left.I_{\sigma}=13.47\right)$ in the Gardon catchment at Mialet $\left(244 \mathrm{~km}^{2}\right)$ (bottom panels).

This study first confirms that, on average, the differences in model performance between lumped and semidistributed options are not significant. However, the analysis applied by catchment and by flood event clearly showed that the impact of spatial rainfall information on flow simulation is scale-dependent, catchment-dependent and eventcharacteristic-dependent. This result underlines that catchment response to spatial heterogeneity of precipitation fields is highly variable between catchments.

The catchments' size and the rainfall intensity coefficient were shown to be effective indicators to identify catchments on which detailed spatial rainfall information is useful to improve simulations. In addition, the indexes proposed by Smith et al. (2004) to evaluate spatial rainfall variability showed that the greatest improvements on streamflow simulation were obtained at the outlet of large catchments and for events with significant spatial variability in precipitation fields.

By investigating catchment responses independently for each catchment and for a variety of flood events, regional tendencies concerning the potential benefit of high spatial rainfall resolution for runoff modeling in France were pointed out. While a better spatial representation of precipitation inputs did not yield better streamflow simulations at the outlet of catchments exposed to oceanic climate conditions, significant improvements were obtained in regions frequently exposed to rainstorms with high spatial variability, such as the Cévennes and the Mediterranean regions.

These results highlight the need to work on large and varied sets of catchments (Gupta et al., 2013). Catchment dependency on rainfall spatial variability is confirmed. By carefully analyzing the changes in simulated hydrographs 
at different spatial resolutions, the significant influence on particular subcatchments can be detected. In this way, the methodology applied in this study provides insights that will aid investigations of the catchment properties that may influence the catchment response.

\subsection{Limits and perspectives}

In spite of our effort to obtain general results, we do see some limits to our conclusions. First of all, we must mention that the results may still be somewhat dependent on the model or testing methodology used, and these may not be adapted to certain particular basin behaviors (Pokhrel et al., 2012; Smith et al., 2012). Here, we have applied a single model structure to all catchments, whereas others would have preferred catchment-specific structures (Fenicia et al., 2011). The spatial heterogeneities in catchment characteristics may interact with the spatial heterogeneity in precipitation fields, with the risk of masking the impact of spatial rainfall variability. Working on optimizing the model structure on a catchmentby-catchment basis could help to resolve a few surprising results, including a few catchments in the Mediterranean region (where the spatial rainfall variability was high) that were not improved with semidistributed modeling (Fig. 13). In addition, substantial improvements due to semidistributed modeling were obtained for a few catchments in central France (Fig. 13 and Table 5), although these catchments were not exposed to strong spatial rainfall variability (Fig. 7); however, these are long catchments with a particular morphology for which streamflow simulations may benefit from the channel-routing function of the semidistributed model. These particular catchments need complementary analysis to validate these hypotheses, which is beyond the scope of this paper.

At this point, we see a natural continuation of this work in further investigations with models whose parameters will be allowed to be distributed spatially, in order to explore the impact of catchment heterogeneities on catchment response. In our opinion, however, this complementary work would not fundamentally modify the conclusions of this paper.

Acknowledgements. The authors thank Météo-France and SCHAPI for providing meteorological and hydrological data, respectively. The first author was supported by a grant from the Pierre and Marie Curie University, Paris, France (ED 398 GRN). The authors also thank Alberto Viglione and Michael Smith for their detailed and constructive review comments, which helped to improve the quality of the manuscript.

Edited by: R. Uijlenhoet

\section{References}

Ajami, N. K., Gupta, H. V, Wagener, T., and Sorooshian, S.: Calibration of a semi-distributed hydrologic model for streamflow estimation along a river system, J. Hydrol., 298, 112-135, doi:10.1016/j.jhydrol.2004.03.033, 2004.

Andréassian, V., Perrin, C., Michel, C., Usartsanchez, I., and Lavabre, J.: Impact of imperfect rainfall knowledge on the efficiency and the parameters of watershed models, J. Hydrol., 250, 206-223, doi:10.1016/S0022-1694(01)00437-1, 2001.

Andréassian, V., Oddos, A., Michel, C., Anctil, F., Perrin, C., and Loumagne, C.: Impact of spatial aggregation of inputs and parameters on the efficiency of rainfall-runoff models: A theoretical study using chimera watersheds, Water Resour. Res., 40, 1-9, doi:10.1029/2003WR002854, 2004.

Andréassian, V., Perrin, C., Berthet, L., Le Moine, N., Lerat, J., Loumagne, C., Oudin, L., Mathevet, T., Ramos, M.-H., and Valéry, A.: HESS Opinions "Crash tests for a standardized evaluation of hydrological models", Hydrol. Earth Syst. Sci., 13, 1757-1764, doi:10.5194/hess-13-1757-2009, 2009.

Apip, Sayama, T., Tachikawa, Y., and Takara, K.: Spatial lumping of a distributed rainfall-sediment-runoff model and its effective lumping scale, Hydrol. Process., 26, 855-871, doi:10.1002/hyp.8300, 2012.

Arnaud, P., Bouvier, C., Cisneros, L., and Dominguez, R.: Influence of rainfall spatial variability on flood prediction, J. Hydrol., 260, 216-230, doi:10.1016/S0022-1694(01)00611-4, 2002.

Arnaud, P., Lavabre, J., Fouchier, C., Diss, S., and Javelle, P.: Sensitivity of hydrological models to uncertainty in rainfall input, Hydrolog. Sci. J., 56, 397-410, doi:10.1080/02626667.2011.563742, 2011.

Bárdossy, A. and Das, T.: Influence of rainfall observation network on model calibration and application, Hydrol. Earth Syst. Sci., 12, 77-89, doi:10.5194/hess-12-77-2008, 2008.

Bell, V. A. and Moore, R. J.: The sensitivity of catchment runoff models to rainfall data at different spatial scales, Hydrol. Earth Syst. Sci., 4, 653-667, doi:10.5194/hess-4-653-2000, 2000.

Bentura, P. and Michel, C.: Flood routing in a wide channel with a quadratic lag-and-route method, Hydrolog. Sci. J., 42, 169-189, doi:10.1080/02626669709492018, 1997.

Berne, A., Delrieu, G., Creutin, J. D., and Obled, C.: Temporal and spatial resolution of rainfall measurements required for urban hydrology, J. Hydrol., 299, 166-179, doi:10.1016/j.jhydrol.2004.08.002, 2004.

Berne, A., Delrieu, G., and Boudevillain, B.: Variability of the spatial structure of intense Mediterranean precipitation, Adv. Water Resour., 32, 1031-1042, doi:10.1016/j.advwatres.2008.11.008, 2009.

Beven, K.: Prophecy, reality and uncertainty in distributed hydrological modelling, Adv. Water Resour., 16, 41-51, doi:10.1016/0309-1708(93)90028-E, 1993.

Beven, K.: The limits of splitting: Hydrology, Sci. Total Environ., 183, 89-97, doi:10.1016/0048-9697(95)04964-9, 1996.

Beven, K.: How far can we go in distributed hydrological modelling?, Hydrol. Earth Syst. Sci., 5, 1-12, doi:10.5194/hess-5-12001, 2001.

Beven, K. and Hornberger, G. M.: Assessing the effect of spatial pattern of precipitation in modeling streamflow hydrographs, J. Am. Water Resour. Assoc., 18, 823-829, doi:10.1111/j.17521688.1982.tb00078.x, 1982. 
Biggs, E. M. and Atkinson, P. M.: A comparison of gauge and radar precipitation data for simulating an extreme hydrological event in the Severn Uplands, UK, Hydrol. Process., 25, 795-810, doi:10.1002/hyp.78692011.

Bonnifait, L., Delrieu, G., Le Lay, M., Boudevillain, B., Masson, A., Belleudy, P., Gaume, E., and Shah, S.: Distributed hydrologic and hydraulic modelling with radar rainfall input: Reconstruction of the 8-9 September 2002 catastrophic flood event in the Gard region (France), Adv. Water Resour., 32, 1077-1089, doi:10.1016/j.advwatres.2009.03.007, 2009.

Borga, M.: Accuracy of radar rainfall estimates for streamflow simulation, J. Hydrol., 267, 26-39, doi:10.1016/S00221694(02)00137-3, 2002.

Boyle, D. P., Gupta, H. V, Koren, V., Zhang, Z., and Smith, M. B.: Toward improved streamflow forecasts: Value of semidistributed modeling, Water Resour., 37, 2749-2759, 2001.

Carpenter, T. and Georgakakos, K. P.: Intercomparison of lumped versus distributed hydrologic model ensemble simulations on operational forecast scales, J. Hydrol., 329, 174-185, doi:10.1016/j.jhydrol.2006.02.013, 2006.

Carpenter, T., Georgakakos, K. P., and Sperfslagea, J.: On the parametric and NEXRAD-radar sensitivities of a distributed hydrologic model suitable for operational use, J. Hydrol., 253, 169193, doi:10.1016/S0022-1694(01)00476-0, 2001.

Cole, S. J. and Moore, R. J.: Hydrological modelling using raingauge- and radar-based estimators of areal rainfall, J. Hydrol., 358, 159-181, doi:10.1016/j.jhydrol.2008.05.025, 2008.

Das, T., Bárdossy, A., Zehe, E., and He, Y.: Comparison of conceptual model performance using different representations of spatial variability, J. Hydrol., 356, 106-118, doi:10.1016/j.jhydrol.2008.04.008, 2008.

Delrieu, G., Nicol, J., Yates, E., Kirstetter, P.-E., Creutin, J.-D., Anquetin, S., Obled, C., Saulnier, G.-M., Ducrocq, V., Gaume, E., Payrastre, O., Andrieu, H., Ayral, P.-A., Bouvier, C., Neppel, L., Livet, M., Lang, M., Du-Châtelet, J. P., Walpersdorf, A., and Wobrock, W.: The Catastrophic Flash-Flood Event of 8-9 September 2002 in the Gard Region, France: A First Case Study for the Cévennes-Vivarais Mediterranean Hydrometeorological Observatory, J. Hydrometeorol., 6, 34-52, doi:10.1175/JHM-400.1, 2005.

Delrieu, G., Braud, I., Berne, A., Borga, M., Boudevillain, B., Fabry, F., Freer, J., Gaume, E., Nakakita, E., and Seed, A.: Weather radar and hydrology, Adv. Water Resour., 32, 969-974, doi:10.1016/j.advwatres.2009.03.006, 2009.

Dodov, B. and Foufoula-Georgiou, E.: Incorporating the spatiotemporal distribution of rainfall and basin geomorphology into nonlinear analyses of streamflow dynamics, Adv. Water Resour., 28, 711-728, doi:10.1016/j.advwatres.2004.12.013, 2005.

Editjano, Nascimento, N., Yang, X., Makhlouf, Z., and Michel, C.: GR3J: a daily watershed model with three free parameters, Hydrolog. Sci. J., 44, 263-277, doi:10.1080/02626669909492221, 1999.

Emmanuel, I., Andrieu, H., and Tabary, P.: Evaluation of the new French operational weather radar product for the field of urban hydrology, Atmos. Res., 103, 20-32, doi:10.1016/j.atmosres.2011.06.018, 2011.
Emmanuel, I., Andrieu, H., Leblois, E., and Flahaut, B.: Temporal and spatial variability of rainfall at the urban hydrological scale, J. Hydrol., 430-431, 162-172, doi:10.1016/j.jhydrol.2012.02.013, 2012.

Faures, J., Goodrich, D. C., Woolhiser, D. A., and Sorooshian, S.: Impact of small-scale spatial rainfall variability on runoff modeling, J. Hydrol., 173, 309-326, doi:10.1016/00221694(95)02704-S, 1995.

Fenicia, F., Kavetski, D., and Savenije, H. H. G.: Elements of a flexible approach for conceptual hydrological modeling: 1. Motivation and theoretical development, Water Resour. Res., 47, 1-13, doi:10.1029/2010WR010174, 2011.

Finnerty, B., Smith, M. B., Seo, D., Koren, V., and Moglen, G.: Space-time scale sensitivity of the Sacramento model to radar-gage precipitation inputs, J. Hydrol., 203, 21-38, doi:10.1016/S0022-1694(97)00083-8, 1997.

Götzinger, J. and Bárdossy, A.: Comparison of four regionalisation methods for a distributed hydrological model, J. Hydrol., 333, 374-384, doi:10.1016/j.jhydrol.2006.09.008, 2007.

Gupta, H. V, Kling, H., Yilmaz, K. K., and Martinez, G. F.: Decomposition of the mean squared error and NSE performance criteria: Implications for improving hydrological modelling, J. Hydrol., 377, 80-91, doi:10.1016/j.jhydrol.2009.08.003, 2009.

Gupta, H. V., Perrin, C., Kumar, R., Blöschl, G., Clark, M., Montanari, A., and Andréassian, V.: Large-sample hydrology: a need to balance depth with breadth, Hydrol. Earth Syst. Sci. Discuss., 10, 9147-9189, doi:10.5194/hessd-10-9147-2013, 2013.

Henderson, F. M.: Open Channel Flow, Macmillan, Prentice Hall, New York, 1966.

Javelle, P., Fouchier, C., Arnaud, P., and Lavabre, J.: Flash flood warning at ungauged locations using radar rainfall and antecedent soil moisture estimations, J. Hydrol., 394, 267-274, doi:10.1016/j.jhydrol.2010.03.032, 2010.

Kampf, S. K. and Burges, S. J.: A framework for classifying and comparing distributed hillslope and catchment hydrologic models, Water Resour. Res., 43, W05423, doi:10.1029/2006WR005370, 2007.

Kirchner, J. W.: Getting the right answers for the right reasons: Linking measurements, analyses, and models to advance the science of hydrology, Water Resour. Res., 42, W03S04, doi:10.1029/2005WR004362, 2006.

Klemeš, V.: Operational testing of hydrological simulation models/Vérification, en conditions réelles, des modèles de simulation hydrologique, Hydrolog. Sci. J., 31, 13-24, doi:10.1080/02626668609491024, 1986.

Koren, V., Finnerty, B., Schaake, J., Smith, M. B., Seo, D., and Duan, Q.: Scale dependencies of hydrologic models to spatial variability of precipitation, J. Hydrol., 217, 285-302, doi:10.1016/S0022-1694(98)00231-5, 1999.

Koren, V., Reed, S., Smith, M. B., Zhang, Z., and Seo, D.-J.: Hydrology laboratory research modeling system (HL-RMS) of the US national weather service, J. Hydrol., 291, 297-318, doi:10.1016/j.jhydrol.2003.12.039, 2004.

Krajewski, W. F., Lakshmi, V., Georgakakos, K. P., and Jain, S. C.: A Monte Carlo Study of Rainfall Sampling Effect on a Distributed Catchment Model, Water Resour. Res., 27, 119-128, doi:10.1029/90WR01977, 1991. 
Krajewski, W. F., Villarini, G., and Smith, J. A.: RADAR Rainfall Uncertainties, B. Am. Meteorol. Soc., 91, 87-94, doi:10.1175/2009BAMS2747.1, 2010.

Kumar, R., Samaniego, L., and Attinger, S.: Implications of distributed hydrologic model parameterization on water fluxes at multiple scales and locations, Water Resour. Res., 49, 1-20, doi:10.1029/2012WR012195, 2013.

Le Moine, N.: Le bassin versant de surface vu par le souterrain: une voie d'amélioration des performances et du réalisme des modèles pluie-débit?, Ph.D. thesis, University of Pierre et Marie Curie, Paris, France, 2008.

Lerat, J.: Quels apports hydrologiques pour les modèles hydrauliques? Vers un modèle intégré de simulation des crues, Ph.D. thesis, University of Pierre et Marie Curie, Paris, France, 2009.

Lerat, J., Andréassian, V., Perrin, C., Vaze, J., Perraud, J. M., Ribstein, P., and Loumagne, C.: Do internal flow measurements improve the calibration of rainfall-runoff models?, Water Resour. Res., 48, W02511, doi:10.1029/2010WR010179, 2012.

Lindström, G., Johansso, B., Persson, M., Gardelin, M., and Bergström, S.: Development and test of the distributed HBV-96 hydrological model, J. Hydrol., 201, 272-288, 1997.

Liu, J., Chen, X., Wu, J., Zhang, X., Feng, D., and Xu, C.-Y.: Grid parameterization of a conceptual distributed hydrological model through integration of a sub-grid topographic index: necessity and practicability, Hydrolog. Sci. J., 57, 282-297, doi:10.1080/02626667.2011.645823, 2012.

Mathevet, T., Michel, C., Andréassian, V., and Perrin, C.: A bounded version of the Nash-sutcliffe criterion for better model assessment on large sets of basins, IAHS Red Books Series, 307, 211-219, 2006.

Merz, R. and Blöschl, G.: A regional analysis of event runoff coefficients with respect to climate and catchment characteristics in Austria, Water Resour. Res., 45, W01405, doi:10.1029/2008WR007163, 2009.

Merz, R., Blöschl, G., and Parajka, J.: Spatio-temporal variability of event runoff coefficients, J. Hydrol., 331, 591-604, doi:10.1016/j.jhydrol.2006.06.008, 2006.

Merz, R., Parajka, J., and Blöschl, G.: Scale effects in conceptual hydrological modeling, Water Resour. Res., 45, W09405, doi:10.1029/2009WR007872, 2009.

Michaud, J. and Sorooshian, S.: Effect of rainfall-sampling errors on simulations of desert flash floods, Water Resour. Res., 30, 2765, doi:10.1029/94WR01273, 1994.

Morin, E., Enzel, Y., Shamir, U., and Garti, R.: The characteristic time scale for basin hydrological response using radar data, J. Hydrol., 252, 85-99, doi:10.1016/S0022-1694(01)00451-6, 2001.

Morris, E. M. and Woolhiser, D. A.: Unsteady one-dimensional flow over a plane: Partial equilibrium and recession hydrographs, Water Resour. Res., 16, 355-360, doi:10.1029/WR016i002p00355, 1980.

Naden, P. S.: Spatial variability in flood estimation for large catchments: the exploitation of channel network structure, Hydrolog. Sci. J., 37, 53-71, 1992.

Nicòtina, L., Alessi Celegon, E., Rinaldo, A., and Marani, M.: On the impact of rainfall patterns on the hydrologic response, Water Resour. Res., 44, W12401, doi:10.1029/2007WR006654, 2008.
Norbiato, D., Borga, M., Merz, R., Blöschl, G., and Carton, A.: Controls on event runoff coefficients in the eastern Italian Alps, J. Hydrol., 375, 312-325, doi:10.1016/j.jhydrol.2009.06.044, 2009.

Obled, C., Wendling, J., and Beven, K.: The sensitivity of hydrological models to spatial rainfall patterns: an evaluation using observed data, J. Hydrol., 159=, 305-333, doi:10.1016/00221694(94)90263-1, 1994.

O'Callaghan, J. F. and Mark, D. M.: The extraction of drainage networks from digital elevation data, Comput. Vis. Graph. Image Proc., 28, 323-344, doi:10.1016/S0734-189X(84)80011-0, 1984.

Ogden, F. L. and Julien, P.: Runoff sensitivity to temporal and spatial rainfall variability at runoff plane and small basin scales, Water Resour. Res., 29, 2589, doi:10.1029/93WR00924, 1993.

Ogden, F. L. and Julien, P.: Runoff model sensitivity to radar rainfall resolution, J. Hydrol., 158, 1-18, doi:10.1016/00221694(94)90043-4, 1994.

Pechlivanidis, I. G., Mclntyre, N. R., and Wheater, H. S.: Calibration of the semi-distributed PDM rainfall-runoff model in the Upper Lee catchment, UK, J. Hydrol., 386, 198-209, doi:10.1016/j.jhydrol.2010.03.022, 2010.

Penna, D., Tromp-van Meerveld, H. J., Gobbi, A., Borga, M., and Dalla Fontana, G.: The influence of soil moisture on threshold runoff generation processes in an alpine headwater catchment, Hydrol. Earth Syst. Sci., 15, 689-702, doi:10.5194/hess-15-6892011, 2011.

Perrin, C., Andréassian, V., Rojas Serna, C., Mathevet, T., and Le Moine, N.: Discrete parameterization of hydrological models: Evaluating the use of parameter sets libraries over 900 catchments, Water Resour. Res., 44, W08447, doi:10.1029/2007WR006579, 2008.

Pokhrel, P. and Gupta, H. V: On the ability to infer spatial catchment variability using streamflow hydrographs, Water Resour. Res., 47, W08534, doi:10.1029/2010WR009873, 2011.

Pokhrel, P., Yilmaz, K. K. and Gupta, H. V: Multiple-criteria calibration of a distributed watershed model using spatial regularization and response signatures, J. Hydrol., 418-419, 49-60, doi:10.1016/j.jhydrol.2008.12.004, 2012.

Reed, S., Koren, V., Smith, M. B., Zhang, Z., MOREDA, F., Seo, D., and Dmipparticipants, a: Overall distributed model intercomparison project results, J. Hydrol., 298, 27-60, doi:10.1016/j.jhydrol.2004.03.031, 2004.

Refsgaard, J. C. and Knudsen, J.: Operational Validation and Intercomparison of Different Types of Hydrological Models, Water Resour. Res., 32, 2189-2202, doi:10.1029/96WR00896, 1996.

Samaniego, L., Kumar, R., and Attinger, S.: Multiscale parameter regionalization of a grid-based hydrologic model at the mesoscale, Water Resour. Res., 46, W05523, doi:10.1029/2008WR007327, 2010.

Saulnier, G. M. and Le Lay, M.: Sensitivity of flash-flood simulations on the volume, the intensity, and the localization of rainfall in the Cévennes-Vivarais region (France), Water Resour., 45, 1 9, doi:10.1029/2008WR006906, 2009.

Schaefli, B. and Gupta, H. V: Do Nash values have value?, Hydrol. Process., 21, 2075-2080, doi:10.1002/hyp.6825, 2007. 
Segond, M.-L., Wheater, H. S., and Onof, C.: The significance of spatial rainfall representation for flood runoff estimation: A numerical evaluation based on the Lee catchment, UK, J. Hydrol., 347, 116-131, doi:10.1016/j.jhydrol.2007.09.040, 2007.

Seibert, J.: On the need for benchmarks in hydrological modelling, Hydrol. Process., 15, 1063-1064, doi:10.1002/hyp.446, 2001.

Shah, S., Oconnell, P., and Hosking, J.: Modelling the effects of spatial variability in rainfall on catchment response, 2. Experiments with distributed and lumped models, J. Hydrol., 175, 89-111, doi:10.1016/S0022-1694(96)80007-2, 1996.

Singh, V. P.: Effect of spatial and temporal variability in rainfall and watershed characteristics on stream flow hydrograph, Hydrol. Process., 11, 1649-1669, doi:10.1002/(SICI)10991085(19971015)11:12<1649::AID-HYP495>3.0.CO;2-1, 1997.

Smith, M. B., Koren, V., Zhang, Z., Reed, S., Pan, J., and MOREDA, F.: Runoff response to spatial variability in precipitation: an analysis of observed data, J. Hydrol., 298, 267-286, doi:10.1016/j.jhydrol.2004.03.039, 2004.

Smith, M. B., Koren, V., Zhang, Z., Zhang, Y., Reed, S., Cui, Z., Moreda, F., Cosgrove, B. A., Mizukami, N., and Anderson, E. A.: Results of the DMIP 2 Oklahoma experiments, J. Hydrol., 418-419, 17-48, doi:10.1016/j.jhydrol.2011.08.056, 2012.

Sun, X., Mein, R., Keenan, T., and Elliott, J.: Flood estimation using radar and raingauge data, J. Hydrol., 239, 4-18, doi:10.1016/S0022-1694(00)00350-4, 2000.

Tabary, P., Dupuy, P., L'Henaff, G., Gueguen, C., Moulin, L., Laurantin, O., Merlier, C., and Soubeyroux, J.-M.: A 10-year (19972006) reanalysis of Quantitative Precipitation Estimation over France: methodology and first results, in: Weather radar and Hydrology, IAHS Publ., 351, 255-260, 2012.

Tarolli, M., Borga, M., Zoccatelli, D., Bernhofer, C., Jatho, N., and Janabi, F.: Rainfall Space-Time Organization and Orographic Control on Flash Flood Response: The Weisseritz Event of August 13, 2002, J. Hydrol. Eng., 18, 183-193, doi:10.1061/(ASCE)HE.1943-5584.0000569, 2013.

Tetzlaff, D. and Uhlenbrook, S.: Significance of spatial variability in precipitation for process-oriented modelling: results from two nested catchments using radar and ground station data, Hydrol. Earth Syst. Sci., 9, 29-41, doi:10.5194/hess-9-29-2005, 2005.
Tramblay, Y., Bouvier, C., Ayral, P.-A., and Marchandise, A.: Impact of rainfall spatial distribution on rainfall-runoff modelling efficiency and initial soil moisture conditions estimation, Nat. Hazards Earth Syst. Sci., 11, 157-170, doi:10.5194/nhess-11157-2011, 2011.

Vaze, J., Post, D. A., Chiew, F. H. S., Perraud, J.-M., Teng, J., and Viney, N. R.: Conceptual rainfall-runoff model performance with different spatial rainfall inputs, J. Hydrometeorol., 12, 11001112, doi:10.1175/2011JHM1340.1, 2011.

Viglione, A., Chirico, G. B., Komma, J., Woods, R., Borga, M., and Blöschl, G.: Quantifying space-time dynamics of flood event types, J. Hydrol., 394, 213-229, doi:10.1016/j.jhydrol.2010.05.041, 2010.

Winchell, M., Gupta, H. V., and Sorooshian, S.: On the simulation of infiltration- and saturation-excess runoff using radarbased rainfall estimates: Effects of algorithm uncertainty and pixel aggregation, Water Resour. Res., 34, 2655-2670, doi:10.1029/98WR02009, 1998.

Woods, R. and Sivapalan, M.: A synthesis of space-time variability in storm response: Rainfall, runoff generation, and routing, Water Resour. Res., 35, 2469-2485, doi:10.1029/1999WR900014, 1999.

Yu, Z., Lu, Q., Zhu, J., Yang, C., Jun, Q., Yang, T., Chen, X., and Sudicky, E.: Spatial and Temporal Scale Effect in Simulating Hydrologic Processes in a Watershed, J. Hydrol. Eng., 1, 99-107, doi:10.1061/(ASCE)HE.1943-5584.0000762, 2012.

Zhang, Z., Smith, M. B., Koren, V., Reed, S., Moreda, F., Kuzmin, V. and Anderson, R.: A study of the relationship between rainfall variability and the improvement of using a distributed model, IAHS-AISH Publ., 289, 188-196, 2004.

Zoccatelli, D., Borga, M., Viglione, A., Chirico, G. B., and Blöschl, G.: Spatial moments of catchment rainfall: rainfall spatial organisation, basin morphology, and flood response, Hydrol. Earth Syst. Sci., 15, 3767-3783, doi:10.5194/hess-15-37672011, 2011. 